\title{
Atmospheric deposition as a source of carbon and nutrients to an alpine catchment of the Colorado Rocky Mountains
}

\author{
N. Mladenov ${ }^{1, *}$, M. W. Williams ${ }^{1,2}$, S. K. Schmidt ${ }^{3}$, and K. Cawley ${ }^{4}$ \\ ${ }^{1}$ Institute for Arctic and Alpine Research, University of Colorado, Boulder, Colorado, USA \\ ${ }^{2}$ Department of Geography, University of Colorado, Boulder, Colorado, USA \\ ${ }^{3}$ Department of Ecology and Environmental Biology, University of Colorado, Boulder, Colorado, USA \\ ${ }^{4}$ Southeast Environmental Research Center, Florida International University, Miami, Florida, USA \\ * now at: Department of Civil Engineering, Kansas State University, Manhattan, Kansas, USA
}

Correspondence to: N. Mladenov(mladenov@ksu.edu)

Received: 25 January 2012 - Published in Biogeosciences Discuss.: 1 March 2012

Revised: 4 July 2012 - Accepted: 28 July 2012 - Published: 24 August 2012

\begin{abstract}
Many alpine areas are experiencing deglaciation, biogeochemical changes driven by temperature rise, and changes in atmospheric deposition. There is mounting evidence that the water quality of alpine streams may be related to these changes, including rising atmospheric deposition of carbon (C) and nutrients. Given that barren alpine soils can be severely $\mathrm{C}$ limited, atmospheric deposition sources may be an important source of $\mathrm{C}$ and nutrients for these environments. We evaluated the magnitude of atmospheric deposition of $\mathrm{C}$ and nutrients to an alpine site, the Green Lake 4 catchment in the Colorado Rocky Mountains. Using a long-term dataset (2002-2010) of weekly atmospheric wet deposition and snowpack chemistry, we found that volume weighted mean dissolved organic carbon (DOC) concentrations were $1.12 \pm 0.19 \mathrm{mg}^{-1}$, and weekly concentrations reached peaks as high at $6-10 \mathrm{mg} \mathrm{l}^{-1}$ every summer. Total dissolved nitrogen concentration also peaked in the summer, whereas total dissolved phosphorus and calcium concentrations were highest in the spring. To investigate potential sources of $\mathrm{C}$ in atmospheric deposition, we evaluated the chemical quality of dissolved organic matter (DOM) and relationships between DOM and other solutes in wet deposition. Relationships between DOC concentration, fluorescence, and nitrate and sulfate concentrations suggest that pollutants from nearby urban and agricultural sources and organic aerosols derived from sub-alpine vegetation may influence high summer DOC wet deposition concentrations. Interestingly, high DOC concentrations were also recorded during "dust-in-snow" events in the spring, which may re-
\end{abstract}

flect an association of DOM with dust. Detailed chemical and spectroscopic analyses conducted for samples collected in 2010 revealed that the DOM in many late spring and summer samples was less aromatic and polydisperse and of lower molecular weight than that of winter and fall samples. Our C budget estimates for the Green Lake 4 catchment illustrated that wet deposition $\left(9.9 \mathrm{~kg} \mathrm{Cha}^{-1} \mathrm{yr}^{-1}\right)$ and dry deposition ( $\left.6.9 \mathrm{kgC} \mathrm{ha}^{-1} \mathrm{yr}^{-1}\right)$ were a combined input of approximately $17 \mathrm{kgCha}^{-1} \mathrm{yr}^{-1}$, which could be as high as $24 \mathrm{~kg} \mathrm{Cha}^{-1} \mathrm{yr}^{-1}$ in high dust years. This atmospheric $\mathrm{C}$ input approached the $\mathrm{C}$ input from microbial autotrophic production in barren soils. Atmospheric wet and dry deposition also contributed $4.3 \mathrm{~kg} \mathrm{Nha}^{-1} \mathrm{yr}^{-1}, 0.15 \mathrm{~kg} \mathrm{Pha}^{-1} \mathrm{yr}^{-1}$, and $2.7 \mathrm{~kg} \mathrm{Ca}^{2+} \mathrm{ha}^{-1} \mathrm{yr}^{-1}$ to this alpine catchment.

\section{Introduction}

In comparison to low elevation ecosystems, alpine environments, often located in remote, high-elevation areas, are particularly sensitive to atmospheric deposition (Psenner, 1999; Ballantyne et al., 2011; Mladenov et al., 2011). There is thus urgency to improve our understanding of how biogeochemical cycling in high-elevation catchments will respond to a combination of climatic changes and changes in atmospheric deposition. For example, atmospheric deposition of nitrogen $(\mathrm{N})$ to mountain catchments has caused numerous changes in ecosystem functions (Williams and Tonnessen, 2000; Baron et al., 2009; Elser et al., 2009). Among these 
is a trend of increasing nitrate export in surface waters that has been observed in many alpine and high-elevation catchments, such as those in the Colorado Rocky Mountains, USA (Williams et al., 2011; Baron et al., 2009), the Alps of northern Italy (Rogora, 2007), and southern Norway (de Wit et al., 2008), for which the process-level controls are just beginning to be explored. Baron et al. (2009) suggested that observed increases in nitrate export from the high-elevation Loch Vale catchment in the Colorado Front Range were the result of warmer temperatures that are melting ice in glaciers and rock glaciers. They proposed that the phenomenon observed in Loch Vale may be indicative of $\mathrm{N}$ release from ice features worldwide as mountain glaciers retreat. Caine (2011) has recently shown that in the Green Lake 4 (GL4) catchment of the Colorado Front Range increasing air temperatures are melting glacial and permafrost ice, increasing the concentrations of both base cations and nitrate in the outflow of GL4. In the Sierra Nevada Mountains, USA, Sickman et al. (2003) and earlier studies by Brooks et al. (1996, 1997) in the Colorado Front Range of the Rocky Mountains provide strong evidence that microbiological processes may also explain the observed increased $\mathrm{N}$ export from high-elevation catchments. Surprisingly, Schmidt et al. (2009) showed that significant nitrification occurs in recently deglaciated soils even on days when the soil temperature (at $5 \mathrm{~cm}$ depth) ranged from $-10^{\circ} \mathrm{C}$ at night to $+30^{\circ} \mathrm{C}$ during the day. Highelevation areas with little or no developed soils have shown large amounts of microbial activity (King et al., 2008; Nemergut et al., 2007), within a few years of deglaciation in some cases (Schmidt et al., 2008). Moreover, overall net production (primary production minus respiration) from alpine soils (Blanken et al., 2009) is negative, which means the $\mathrm{C}$ loss from microbial respiration probably exceeds the autotrophic $\mathrm{C}$ production in these systems.

Despite the high microbial activity observed in barren alpine soils, these environments and the microbial communities in them are also severely carbon-limited (Williams et al., 1997, 2007; Brooks and Williams, 1999; King et al., 2008). It is currently unclear how microbial communities in oligotrophic soils obtain the carbon (C) and energy necessary to sustain life. In many regions, these soils are snow covered for more than 9 months of the year, and the short snow-free period provides limited time for the acquisition of $\mathrm{C}$ and nutrients (Ley et al., 2004). The $\mathrm{C}$ budget for alpine catchments is not well constrained, and mounting evidence for active $\mathrm{C}$ cycling in alpine lakes and soils suggests that allochthonous delivery of $\mathrm{C}$ and other nutrients may be extremely important.

Atmospheric aerosol transport is one vector for the delivery of $\mathrm{C}$ and other nutrients to alpine areas. In arid regions of the western US and southern Europe, dust emissions can result in substantial nutrient subsidies in the form of $\mathrm{Fe}, \mathrm{P}$, and N (Neff et al., 2008; Lawrence and Neff, 2009; Ballantyne et al., 2011; Reche et al., 2009). Given phosphorus (P) limitation or co-limitation in many alpine areas (Elser et al.,
2009; King et al., 2008), dust-derived and other atmospheric $\mathrm{P}$ inputs may be especially important.

Whereas the inorganic fraction of atmospheric deposition is relatively well measured in the US, mainly in precipitation chemistry by the National Atmospheric Deposition Program (NADP; http://nadp.sws.uiuc.edu/), there are few quantitative studies of organic $\mathrm{C}$ in atmospheric deposition and even fewer for atmospheric deposition in alpine environments. Precipitation has been shown to be an important $\mathrm{C}$ input for carbon-poor environments, such as coastal areas (Kieber et al., 2006, 2007) and the open ocean (Willey et al., 2000, Economu and Mihalopoulos, 2002, Jurado et al., 2008). For alpine environments, Litaor (1987) and Ley et al. (2004) in the Colorado Rocky Mountains and more recently Mladenov et al. $(2009,2010)$ in the Sierra Nevada of Spain reported that aeolian deposition comprised about $10 \%$ to $20 \%$ organic C. Lawrence et al. (2010) also found surprisingly high organic $\mathrm{C}$ content in dust deposition.

Mladenov et al. (2009) used spectroscopic techniques (UV-vis absorbance and fluorescence) in combination with air mass backward trajectories to demonstrate that water soluble organic carbon (WSOC) from dust emitted in Africa and deposited at an alpine site in Spain contained substantial amounts of humic-like fluorescent compounds. The humic-like fraction (HULIS) of atmospheric aerosols is becoming increasingly studied, yet the sources and chemical quality of this fraction are still a matter of debate (Graber and Rudich, 2006). A number of recent studies have suggested that the optical properties of chromophoric water soluble organic compounds in air may be similar to chromophoric DOM (CDOM) in water (Kiss et al., 2003; Kieber et al., 2006; Duarte et al., 2007). Absorbance and fluorescence spectra of WSOC in the ultraviolet (UV) and visible range have been shown to bear some similarity to those of aquatic humic substances (Graber and Rudich, 2006 and references therein). However, stronger evidence for the similarities between atmospheric HULIS and aquatic humic substances lies in measures of UV-vis and fluorescence ratios and DOC-normalized specific UV absorbance (SUVA or specific absorptivity) (Kiss et al., 2003; Duarte et al., 2005, 2007; Kieber et al., 2006). For example, Duarte et al. (2005) found that WSOC in autumn aerosols from wood combustion sources had higher degrees of aromaticity (from ${ }^{13} \mathrm{C}$-nuclear magnetic resonance $\left({ }^{13} \mathrm{C}-\mathrm{NMR}\right)$ spectroscopy and fourier transform infrared (FT-IR) spectroscopy), specific absorptivity and specific fluorescence intensity than summer samples. These differences were attributed to the presence of lignaceous and other aromatic compounds from wood burning in autumn samples. This is consistent with studies in aquatic environments where SUVA at $254 \mathrm{~nm}$ has been shown to be well correlated to aromaticity, and SUVA is often used as a surrogate for aromaticity (Weishaar et al., 2003). In addition, the use of UV-vis absorbance, fluorescence, and molecular weight to describe photodegradation effects on CDOM in the water column has also been applied to the study of rainwater 
(Kieber et al., 2007) and WSOC of aerosols (Nakajima et al., 2008).

Here, we compile data from long-term monitoring (20022010) of water quality in atmospheric wet deposition and the snowpack to investigate the importance of atmospheric wet and dry inputs of water soluble $(<0.7 \mu \mathrm{m})$ organic carbon and nutrients such as nitrogen, phosphorus, and calcium, for a remote, high-elevation watershed in the Colorado Rocky Mountains, USA. We also seek to better understand the chemical quality of high-elevation atmospheric $\mathrm{C}$ inputs by examining the molecular weight and optical spectroscopic properties of DOM in 2010 wet deposition.

\section{Site description}

The upper Green Lakes Valley is an east-facing glacial valley located on the Continental Divide in the Colorado Front Range $\left(40^{\circ} 03^{\prime} \mathrm{N}, 105^{\circ} 35^{\prime} \mathrm{W}\right.$; Fig. 1). Named for a series of shallow paternoster lakes, the Green Lakes Valley is the headwaters of North Boulder Creek and lies within the City of Boulder Watershed. Green Lakes Valley is part of the Niwot Ridge (NWT) Long-Term Ecological Research (LTER) network site and also the Boulder Creek Critical Zone Observatory. The upper valley is approximately $225 \mathrm{ha}$ in area, and the elevation ranges from $4084 \mathrm{~m}$ at the Continental Divide to $3515 \mathrm{~m}$ at the outlet of GL4 (Fig. 1).

The continental, high-mountain climate of Green Lakes Valley has been recorded continuously at the D-1 meteorological station on Niwot Ridge (Fig. 1) for over $40 \mathrm{yr}$ (Greenland, 1989). Mean annual temperature at D-1 is $-3.7^{\circ} \mathrm{C}$ (Williams et al., 1996). Almost $80 \%$ of the approximately $1000 \mathrm{~mm}$ of recorded annual precipitation falls as snow (Caine, 1996). The bulk snow pack temperature remains below $0{ }^{\circ} \mathrm{C}$ until late spring, introducing a lag in the hydrological cycle by concentrating the release of melt water in a short, intense period of runoff (Caine, 1996).

Niwot Ridge forms the northern boundary of the Green Lakes Valley, and is the site of other experimental areas, including snow lysimeters, a subnivean laboratory and an Aerometrics wet-chemistry precipitation collector at the Saddle CO02 site $(3520 \mathrm{~m}$ a.s.l.; Fig. 1) operated as part of the NADP. The NWT LTER program operates a second Aerometrics wet-chemistry precipitation collector following NADP protocols at the Soddie site (3345 m a.s.l.). However, this site is not part of the NADP network, which allows the NWT LTER program to analyze wet deposition samples for solutes not analyzed as part of NADP, including dissolved organic carbon (DOC), dissolved organic nitrogen (DON), total dissolved phosphorus (TDP), dissolved organic phosphorus (DOP), and stable water isotopes.

\section{Methods}

\subsection{Sample collection}

\subsubsection{Precipitation and snow}

Physical and chemical properties of snow are measured on a weekly basis at the Saddle and Soddie sites on Niwot Ridge; detailed sampling protocols have been presented in Williams et al. (1999, 2009). Precipitation quantity is measured as part of the NWT LTER program. Weekly wet deposition quality is measured in samples collected in precipitation collectors at the NADP Saddle CO02 site and the NWT LTER Soddie site (Fig. 1). However, the first 200-300 $\mathrm{ml}$ of the NADP CO02 collector sample were reserved for the NADP and frequently there was not enough volume for DOC and other organic species analyses. Therefore, this study reports results from the more complete dataset of the Soddie collector, located at treeline.

Snow was sampled weekly at the SSW site adjacent to the Soddie collector and annually at the time of maximum accumulation (mid-May) at multiple sites (ARK, NAV, 084, 085, 087, 088, and adjacent to GL4 and Green Lake 5 (GL5); Fig. 1). Snow depth measurements were made at $>500$ sites in the GL4 catchment. Snow density was measured at $>8$ points (SSW, 006, 084, 085, 087, 088, GL4, GL5, ARK, and NAV sites), and those data together with snow depth were used to calculate the snow water equivalent (SWE). Here, we present both precipitation and snowpack values from 2002 to 2010 . For 2010 we also evaluated the quality of organic matter using a variety of techniques, which are presented below.

\subsubsection{Surface water}

From 2002 to 2010, surface waters were collected as grab samples at the outlet of GL4 (Fig. 1). Polyethylene bottles were soaked with deionized (DI) water overnight and then rinsed with DI water five times; bottles were further rinsed three times with sample water at the time of collection. Water samples for dissolved organic matter analyses were collected in precombusted amber glass bottles with Teflon-lined caps and filtered through precombusted glass fiber filters with a nominal pore size of $0.7 \mu \mathrm{m}$. Samples for stable water isotopes were collected in 30-ml borosilicate vials with airtight caps. All water samples were transported the same day as collection to the wet chemistry laboratory and stored at $4{ }^{\circ} \mathrm{C}$ until analysis. Similar to wet deposition samples, the quality of organic matter from the outlet of GL4 was evaluated for 2010.

\subsection{Water chemistry analyses}

All wet deposition, surface water, and snow samples were analyzed for $\mathrm{pH}$, specific conductance, ammonium $\left(\mathrm{NH}_{4}\right)$, calcium $\left(\mathrm{Ca}^{2+}\right)$, nitrate $\left(\mathrm{NO}_{3}^{-}\right)$, sulfate $\left(\mathrm{SO}_{4}^{2-}\right)$, DOC, total 


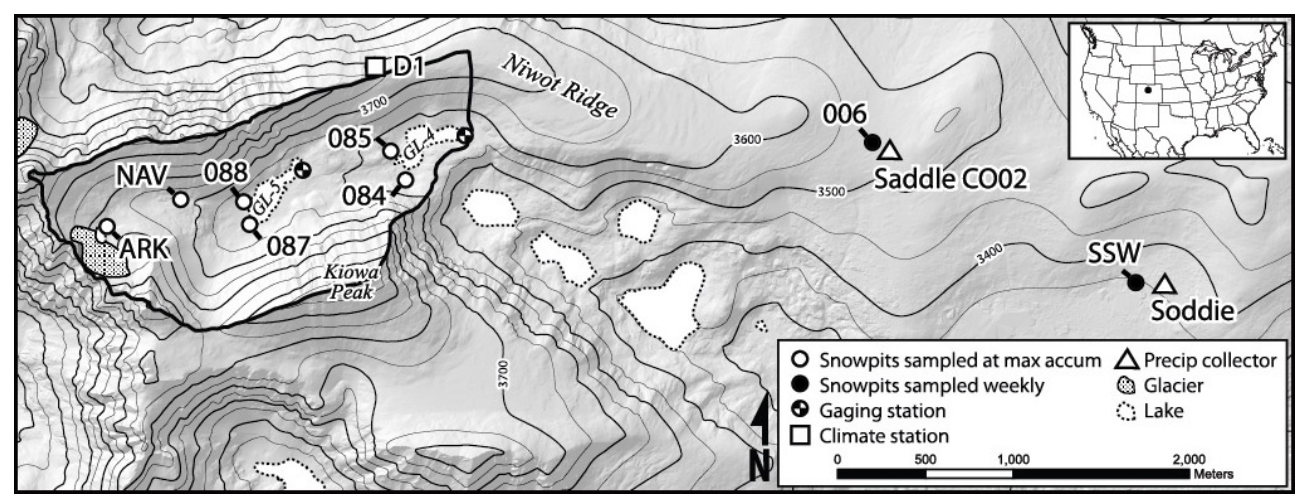

Fig. 1. Map of Niwot Ridge and the Green Lake 4 (GL4) catchment (outlined), showing Green Lake 4 (GL-4), Green Lake 5 (GL-5), the gauging station at GL-4, the D1 climate station, sites of wet deposition (Saddle site NADP collector CO02 and Soddie site collector) and snow sampling. Inset shows the location of the Niwot Ridge LTER, Colorado, USA. Art credit: Parrish, E.

nitrogen (TN), total dissolved nitrogen (TDN), total phosphorus (TP), total dissolved phosphorus (TDP), and a stable isotope of oxygen $\left(\delta^{18} \mathrm{O}\right)$ at the Institute for Arctic and Alpine Research (INSTAAR) in Boulder, CO. Snow samples were stored frozen $\left(-20^{\circ} \mathrm{C}\right)$ for 1 to 2 months until analysis. Blank samples of distilled DI water stored in sample bags for the same amount of time showed no significant contamination from the bags (Williams et al., 1992). Snow samples were placed in covered polyethylene buckets and melted overnight at room temperature. Samples for chemical and nutrient content were analyzed at the Kiowa wet chemistry laboratory run by the Niwot Ridge (NWT) LTER program, following the protocols presented in Williams et al. (2006). Dissolved species of interest (DOC, TDN, and TDP) are referred to as "water soluble" compounds. Specific conductance and $\mathrm{pH}$ were measured immediately after melting for snow or after return to the laboratory for water samples using the Gran titration technique. Subsamples were immediately filtered through pre-combusted and pre-rinsed $(300 \mathrm{ml}), 47-$ mm Whatman or Gelman A/E glass fiber filters with an effective pore size of $0.7 \mu \mathrm{m}$. Filtered samples were stored in the dark at $4{ }^{\circ} \mathrm{C}$ for subsequent analyses within 1 to 4 weeks.

The instruments and methods used to analyze each solute and detection limits for each are listed in Supplement Table S1. In brief, DOC concentrations were measured by high temperature catalytic oxidation on the Shimadzu series of instruments (Supplement Table S1). Particulate organic carbon (POC) was calculated as the difference between nonpurgeable organic carbon in unfiltered samples and filtered samples. TN and TDN were determined on unfiltered and filtered samples, respectively, by potassium persulfate digestion to oxidize all dissolved forms of $\mathrm{N}$ into $\mathrm{NO}_{3}-\mathrm{N}$. DON was calculated by subtracting measured inorganic $\mathrm{N}\left(\mathrm{NO}_{3}-\right.$ $\mathrm{N}-\mathrm{NH}_{4}-\mathrm{N}$ ) from the TN value of the filtered sample. Particulate nitrogen (PN) was calculated as the difference between TN and TDN. TP and TDP were determined on unfiltered and filtered samples, respectively, by digestion using the Lachat Quik Chem series of instruments (Supplement Table S1). Particulate phosphorus (PP) was calculated as the difference between TP and TDP. $\mathrm{Ca}^{2+}$ was determined using the Perkin Elmer Atomic Absorption instruments (Supplement Table S1).

Isotopic analyses of ${ }^{18} \mathrm{O}$ were conducted on unfiltered samples using the $\mathrm{CO}_{2}-\mathrm{H}_{2} \mathrm{O}$ equilibration technique at the Stable Isotope Laboratory at INSTAAR. The ${ }^{18} \mathrm{O}$ values are expressed in conventional delta $(\delta)$ notation in units of per mil $(\% o)$ relative to Vienna standard mean ocean water (VSMOW) with a precision of $\pm 0.05 \%$ :

$$
\begin{aligned}
\delta^{18} \mathrm{O}= & {\left[\left({ }^{18} \mathrm{O} /{ }^{16} \mathrm{O}\right)_{\text {sample }}-\left({ }^{18} \mathrm{O} /{ }^{16} \mathrm{O}\right)_{\text {VsMow }}\right] / } \\
& \left({ }^{18} \mathrm{O} /{ }^{16} \mathrm{O}\right)_{\text {VsMOw }} \times 1000 .
\end{aligned}
$$

Analytical bias was assessed through charge balance calculations using calibrated standards. An ecosystem proficiency blind survey was performed in June and July 2004 through Environment Canada to assess the accuracy of the anion and cation methodologies. Analytical precision for all solutes was assessed with spikes, blanks, and replicates. More information can be found on the Kiowa Environmental Chemistry Laboratory website (http://snobear.colorado.edu/ Seiboldc/kiowa.html).

\subsection{Size exclusion chromatography}

Size exclusion chromatography (SEC) analysis was performed on a Thermo Scientific HPLC system equipped with a photodiode array (PDA Plus detector) at Florida International University in Miami, FL, using a method similar to Maie et al. (2004). Briefly, $100 \mu$ l of filtered water was injected onto an YMC-Pack Diol-120 column. The mobile phase, flow rate $0.7 \mathrm{ml} \mathrm{min}^{-1}$, was comprised of $0.05 \mathrm{M}$ tris(hydroxymethyl)aminomethane (THAM) buffer adjusted to a pH of 7 with concentrated phosphoric acid. The UV-Vis detector collected the absorbance at $280 \mathrm{~nm}$. Molecular weight averages and polydispersity were calculated from 
the sample chromatograms between retention times of 1425 min according to Maie et al. (2004) using standards of polystyrene (MW =1400, 4300, 6800, $13000,36000 \mathrm{Da}$ ), blue dextran, and glycine. Average molecular weight values presented here serve as a guide along the MW continuum and are not actual values (e.g., Scully et al., 2004).

\subsection{UV-vis absorbance measurements}

UV-vis absorbance was determined from 200 to $900 \mathrm{~nm}$ in a 1-cm path length quartz cuvette using an Agilent 8453 UVvis spectrophotometer. UV-vis absorbance was measured in duplicate for each sample, and for the wavelength range of interest ( 250 to $500 \mathrm{~nm}$ ), the standard deviations always were $<1 \%$ of the measured absorbance. The photometric accuracy of the instrument is $< \pm 0.005$ arbitrary units (AU). The mean absorbance from 790 to $800 \mathrm{~nm}$ was subtracted from all spectral absorbance values to remove scattering effects (Mitchell et al., 2003). Absorbance at $250 \mathrm{~nm}$ and $320 \mathrm{~nm}$ wavelengths were expressed as Naperian absorption coefficients $\left(a_{250}\right.$ and $\left.a_{320}\right)$. Absorption at $250 \mathrm{~nm}$ reflects absorbance by aromatic moieties, and absorption at $320 \mathrm{~nm}$ is commonly used to refer to UV transparency in the water column (Morris et al., 1995). We also calculated the specific UV absorbance (SUVA), a DOC concentration-normalized absorbance value at $254 \mathrm{~nm}$ as specified in Weishaar et al. (2003). The spectral slopes from 275 to $295 \mathrm{~nm}$ and 350 to $400 \mathrm{~nm}$ were calculated as the slope values of the linear regression of the log-transformed absorption spectra (Helms et al., 2008). A dimensionless parameter, the slope ratio $\left(S_{\mathrm{R}}\right)$, was calculated as the ratio of the slope of the shorter wavelength region (275-295 nm), $S_{275-295}$, to that of the longer wavelength region (350-400 nm), $S_{350-400}$ (Helms et al., 2008).

\subsection{Fluorescence spectral acquisition}

A fraction of CDOM that emits fluorescence when excited with UV and visible light is known as fluorescent DOM (FDOM) (Coble, 2007). Fluorescence spectroscopy provides compositional and chemical information about this fluorescing DOM pool. Excitation emission matrices (EEMs) are a 3-dimensional representation of fluorescence intensities scanned over a range of excitation/emission (ex/em) wavelengths. Prominent humic peaks have been identified, such as in Region A (at ex/em 240-260/380-460 nm) and Region C (at ex/em 320-350/420-480 nm) (Coble, 1996). Other peaks have been attributed to tyrosine and tryptophan amino acid-like fluorescence at ex/em 275/310 nm and $275 / 340 \mathrm{~nm}$ (Coble, 1996), but other compounds may also fluoresce in these low excitation/emission regions (Mladenov et al., 2011). EEMs were collected with a JY-Horiba Spex Fluoromax-3 spectrophotometer at room temperature using $5 \mathrm{~nm}$ excitation and emission slit widths, an integration time of $0.25 \mathrm{~s}$, an excitation range of $240-450 \mathrm{~nm}$ at
$10 \mathrm{~nm}$ increments, and an emission range of $300-560 \mathrm{~nm}$ at $2 \mathrm{~nm}$ increments. To correct for lamp spectral properties and to compare results with those reported in other studies, spectra were collected in signal-to-reference $(S: R)$ mode with instrument-specific excitation and emission corrections applied during post-processing. EEMs were normalized to the Raman area to account for lamp decay over time and to compare with other studies. Raman-normalized Milli-Q blanks were subtracted to remove the Raman scattering signal. Instrument-specific corrections, Raman area normalization, blank subtraction, and generation of EEMs were performed using MATLAB (version R2009b). We determined the two-dimensional fluorescence index (FI) to evaluate microbial and terrestrial contributions to the DOM pool (McKnight et al., 2001). The FI was calculated as the ratio of fluorescence intensities at $470 \mathrm{~nm}$ to $520 \mathrm{~nm}$ for an excitation at $370 \mathrm{~nm}$. After all corrections, EEM spectra are highly reproducible with a standard error for FI of $<0.02$.

\subsection{PARAFAC model}

EEM spectral acquisition together with parallel factor analysis (PARAFAC) modeling was used to obtain quantitative information about the distribution of fluorescent components (Stedmon et al., 2003). The remote lake PARAFAC model, described in Mladenov et al. (2011), included 105 remote and high-elevation alpine lake samples and was validated using split-half validation and random initialization according to Stedmon and Bro (2008). PARAFAC distributions were obtained by fitting each EEM to the model, and fits were considered suitable if intensities in the residual EEMs, generated by subtracting the PARAFAC modeled EEM from the measured EEM, were $<10 \%$ of measured intensities. PARAFAC components and their excitation and emission maxima are plotted in Supplement Fig. S1. At low emission wavelengths $(<350 \mathrm{~nm})$, fluorescent signatures of the plastic NADP bucket blank were high when water was in contact with the bucket for up to one week (Supplement Fig. S2). Therefore, we did not use spectral information acquired at wavelengths $<350 \mathrm{~nm}$. Here, we report the total fluorescence $\left(F_{\text {total }}\right)$ and the fluorescence loading of each relevant component with a peak $>350 \mathrm{~nm}$ emission (LC1, LC2, LC3) in Raman units (RU). The standard error, calculated from the PARAFAC distributions of duplicate EEMs, associated with relative amounts of each component is $<0.5 \%$.

\subsection{Statistical analyses}

Data that were not normally distributed were transformed to meet the assumptions of normality necessary for regression analyses. To examine significant differences, categorized means with $95 \%$ confidence intervals were calculated. One-way ANOVA analyses with site or season as the categorical predictor were used in combination with an unequal N HSD post-hoc test to evaluate significance of differences. 
Bivariate correlations, linear regressions and all other statistical analyses were performed with Statistica 9.

\subsection{Backward trajectory analyses}

For representative wet deposition samples, we examined the source of air masses over Niwot Ridge in the Colorado Rocky Mountains $\left(40.05^{\circ} \mathrm{N}, 105.57^{\circ} \mathrm{W}\right)$ by computing backward trajectories (http://www.arl.noaa.gov/ready. html) on dates with precipitation. Exact dates of precipitation were identified from precipitation gage data at 10 min intervals measured at the Soddie site and made available through the NWT LTER. Using the time of a storm as the starting point, four consecutive backward trajectories with $48 \mathrm{~h}$ run time were computed at $6 \mathrm{~h}$ intervals using the HYSPLIT model (Draxler and Rolph, 2003) and archived data from the Global Data Assimilation System (GDAS) meteorological dataset.

\subsection{Volume-weighted mean concentrations, loadings, and yields of soluble species}

Annual volume-weighted mean (VWM) concentrations of solutes in wet deposition were calculated as the sum of the product of weekly solute concentrations and weekly wet deposition volumes divided by the sum of weekly wet deposition volume values for each year. Annual volume-weighted mean concentrations of solutes in GL4 were calculated as the sum of the product of weekly solute concentrations and weekly discharge at the outlet of GL4 divided by the sum of weekly discharge from the lake for each year.

Wet deposition is reported as a catchment loading $\left(\mathrm{kg} \mathrm{yr}^{-1}\right)$ or areal loading $\left(\mathrm{kg} \mathrm{ha}^{-1} \mathrm{yr}^{-1}\right)$. Weekly loadings of solutes were calculated by multiplying the precipitationweighted mean solute concentration $\left(\mathrm{mgl}^{-1}\right)$ by the total gauge precipitation amount in centimeters for the summary period and dividing by 10, as per NADP protocols (http:// nadp.sws.uiuc.edu/documentation/notes-depo.html). Annual loadings of solutes in wet deposition, $M_{\text {annual-wet }}$, to the GL4 catchment were calculated as the sum of weekly loadings.

We also calculated the loading of DOC in wet deposition between the end of October (approximate start of snow accumulation) and mid-May (approximate date of maximum accumulation of the snowpack), $M_{\text {max-wet }}$.

Solute yields from GL4 were calculated as the product of daily lake solute concentrations and daily discharge from the lake, summed for the entire snow-free period. Values below detection limits were treated as zero values (Williams et al., 2006).

\subsection{Dry deposition loading}

Dry deposition is reported as a catchment loading $\left(\mathrm{kg} \mathrm{yr}^{-1}\right)$ or areal loading $\left(\mathrm{kg} \mathrm{ha}^{-1} \mathrm{yr}^{-1}\right)$. The dry deposition loading of water soluble compounds in the snowpack from the start of snow accumulation (end of October) to the date of maxi- mum accumulation of the snowpack (mid-May), $M_{\text {max-dryws }}$, was calculated as the difference between the total solute mass in the snow at maximum accumulation, $M_{\text {max-snow }}$, and the cumulative solute mass in wet deposition (mainly snow) at maximum accumulation, $M_{\text {max }}$ wet, as follows:

$M_{\text {max-dryWS }}=M_{\text {max-snow }}-M_{\text {max-wet }}$.

The annual dry deposition loading of water soluble compounds, $M_{\text {annual-dryws, }}$, was then calculated as follows:

$M_{\text {annual-dryWs }}=M_{\text {max-dryWs }}\left(M_{\text {annual-wet }}: M_{\text {max-wet }}\right)$,

where $M_{\text {annual-wet }}: M_{\text {max-wet }}$ is the ratio of the mean annual wet deposition loading to the cumulative wet deposition loading at maximum accumulation.

The dry deposition-derived loading of particulate compounds in the snowpack from the start of snow accumulation (end of October) to the date of maximum accumulation of the snowpack (mid-May), $M_{\text {max-dryP }}$, was taken as the particulate fraction of each solute. POC, PN, and PP concentrations were measured in the snowpack at maximum accumulation from 2002-2004. The annual dry deposition loading of particulate compounds, $M_{\text {annual-dryP, }}$ was then calculated as follows:

$M_{\text {annual-dryP }}=M_{\text {max-dryP }}\left(M_{\text {annual-wet }}: M_{\text {max-wet }}\right)$.

\subsection{Pollen in atmospheric deposition and pollen leaching experiments}

We counted pollen in wet and dry deposition using microscopy with flow cytometry (FlowCAM) technology (N. Goss, unpublished, 2012). Pollen was between 30 and $80 \mu \mathrm{m}$ in diameter and easily detectable due to its high opacity. To determine the amount of $\mathrm{C}$ leached from pollen, known masses of two common Rocky Mountain pollen species, Pinus ponderosa (Ponderosa pine) and P. contorta (Lodgepole pine), were leached in ultra-pure water. Because wet deposition samples may be in the collector for up to one week, we leached pollen for $20 \mathrm{~min}, 24 \mathrm{~h}$, and 1 week to represent a range of contact times between pollen and wet deposition. At each of these time steps, a well-mixed subsample of the pollen-water slurry was filtered with a GFF filter, and the DOC concentration was measured as described previously. The number of pollen grains in the $P$. ponderos $a$ and $P$. contorta experiments was counted on the FlowCAM for well-mixed, triplicate, unfiltered $5 \mathrm{ml}$ subsamples. The DOC concentration per $\mathrm{g}$ of pollen was determined by multiplying the DOC concentration by the volume of the subsample and dividing by the mass of pollen added. We also estimated the contribution of DOC leached from pollen during the week of highest pollen deposition in 2011 (15-21 June; N. Goss, unpublished, 2012) to the DOC concentration of wet deposition during that week. To do this, we estimated the DOC concentration per pollen grain by multiplying the DOC concentration by the volume of the subsample and dividing by 
the total number of pollen grains in each experiment. We then multiplied the DOC concentration per pollen grain by the total number of pollen grains in the 15-21 June 2011 wet deposition sample.

\section{Results}

\subsection{DOM and nutrients in wet deposition and snowpack}

Mean DOC, TDN, TDP, and $\mathrm{Ca}^{2+}$ concentrations measured at the Soddie collector were nearly identical to those measured at the NADP CO02 collector (Supplement Fig. S3), even though there is an elevational difference of $175 \mathrm{~m}$ between the two collectors. During the 2002 to 2010 period, the annual VWM DOC concentration in wet deposition at Soddie ranged from 0.77 to $1.41 \mathrm{mg} \mathrm{Cl}^{-1}$ with a mean value of $1.12 \pm 0.19 \mathrm{mg} \mathrm{Cl}^{-1}$ (Table 1). Weekly DOC reached concentrations as high as $6-10 \mathrm{mg} \mathrm{Cl}^{-1}$ (Fig. 2).

The DOC loading in wet deposition from 2002-2010 ranged from 5.7 to $19 \mathrm{~kg} \mathrm{Cha}^{-1} \mathrm{yr}^{-1}$ with a mean value of $9.9 \pm 4.2 \mathrm{kgCha}^{-1} \mathrm{yr}^{-1}$ (Table 1) and represented the greatest loading of all solutes in wet deposition (Supplement Table S2). The highest annual DOC loading in wet deposition, $19 \mathrm{~kg} \mathrm{Cha}^{-1} \mathrm{yr}^{-1}$, was measured in 2006 , a year with high dust deposition (Rhoades et al., 2010). Mean TDN and $\mathrm{Ca}^{2+}$ loadings were $3.8 \pm 1.1 \mathrm{~kg} \mathrm{Nha}^{-1} \mathrm{yr}^{-1}$ and $2.7 \pm 1.7 \mathrm{~kg} \mathrm{Ca}^{2+} \mathrm{ha}^{-1} \mathrm{yr}^{-1}$, respectively (Table 1), whereas DON, TDP, DOP loadings were orders of magnitude lower (Table 1 and Supplement Table S2).

Annual yields of DOC, TDN, TDP, and $\mathrm{Ca}^{2+}$ in GL4 were $2007 \mathrm{~kg} \mathrm{C}, 693 \mathrm{~kg} \mathrm{~N}, 5.78 \mathrm{~kg} \mathrm{P}$, and $4604 \mathrm{~kg} \mathrm{Ca}^{2+}$, respectively (Table 2). A comparison of wet deposition and lake yield showed atmospheric loadings of DOC, TDN, and TDP on the same order of magnitude as yields from the lake (Table 2). $\mathrm{Ca}^{2+}$ in wet deposition was nearly an order of magnitude lower than yield of $\mathrm{Ca}^{2+}$ from the lake (Table 2).

The cumulative DOC loading in snow at maximum accumulation, calculated from DOC concentrations measured just prior to the ionic pulse (Williams et al. 2009) and from the SWE (Table 3), ranged from 2.0 to $6.1 \mathrm{~kg} \mathrm{Cha}^{-1} \mathrm{yr}^{-1}$ during the 2002-2010 period, with a mean value of $3.5 \mathrm{~kg} \mathrm{Cha}^{-1} \mathrm{yr}^{-1}$ (Table 4). For TDN and TDP, the loadings ranged from 1.0 to $2.3 \mathrm{~kg} \mathrm{Nha}^{-1} \mathrm{yr}^{-1}$ and 0.02 to $0.05 \mathrm{~kg} \mathrm{Pha}^{-1} \mathrm{yr}^{-1}$ (Table 4). $\mathrm{Ca}^{2+}$ loadings in snow at maximum accumulation ranged from 0.8 to $3.7 \mathrm{~kg} \mathrm{Ca}^{2+} \mathrm{ha}^{-1} \mathrm{yr}^{-1}$ and were highest in 2006 and 2010 (Table 4). These loadings correspond to $788 \mathrm{~kg} \mathrm{Cyr}^{-1}$, $351 \mathrm{~kg} \mathrm{Nyr}^{-1}, 8 \mathrm{~kg} \mathrm{Pyr}^{-1}$ and $438 \mathrm{~kg} \mathrm{Ca}^{2+} \mathrm{yr}^{-1}$ in the snowpack of the catchment at maximum accumulation (Table 4).

The wet deposition inputs of DOC, TDN, TDP and $\mathrm{Ca}^{2+}$ at maximum accumulation, $M_{\text {max-wet }}$, represented on average $3.6 \mathrm{~kg} \mathrm{Cha}^{-1}, 1.9 \mathrm{~kg} \mathrm{TDN} \mathrm{ha}^{-1}, 0.01 \mathrm{~kg} \mathrm{TDP} \mathrm{ha}^{-1}$, and $2.0 \mathrm{~kg} \mathrm{Ca}^{2+} \mathrm{ha}^{-1}$ (Table 5). These values together with
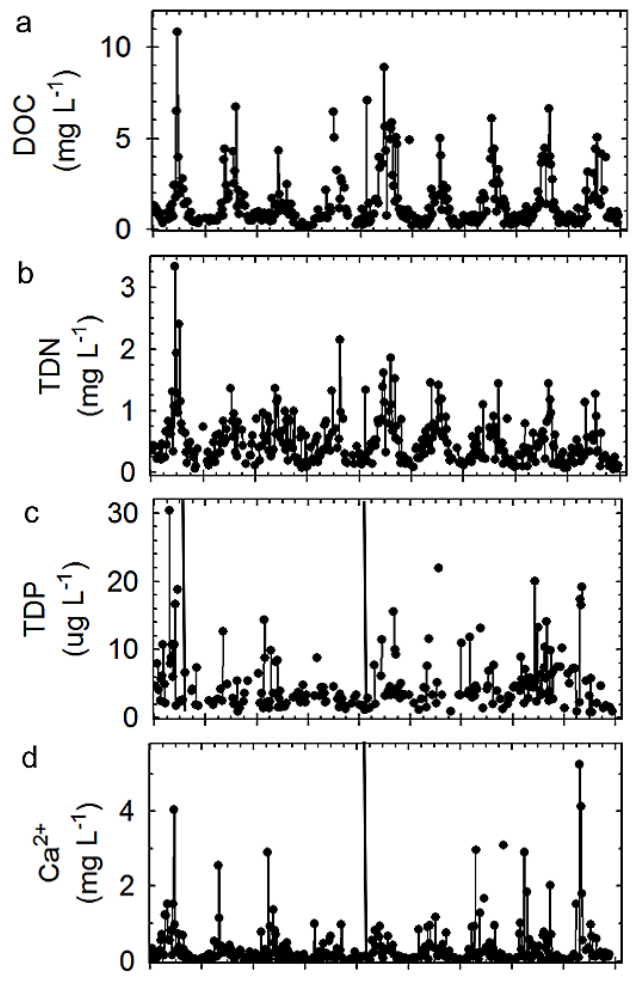

Jan-02 Jan-04 Jan-06 Jan-08 Jan-10

Fig. 2. Concentrations of (a) DOC, (b) TDN, (c) TDP and (d) $\mathrm{Ca}^{2+}$ in wet deposition. TDP and $\mathrm{Ca}^{2+}$ concentrations from 21 February 2006 were outside of the range shown on these figures, at $65 \mathrm{~g} \mathrm{Pl}^{-1}$ and $10.5 \mathrm{mg} \mathrm{Ca}^{-1}$, respectively.

$M_{\text {annual-wet }}$ values, used to calculate dry deposition inputs, are shown in Table 5 along with data for 2002 and 2006, the years with the highest and lowest $M_{\text {annual-wet }}$ OC values, respectively.

\subsection{DOM and nutrients in dry deposition}

For DOC, TDN and $\mathrm{Ca}^{2+}$, mean $M_{\text {max-wet }}$ values for the period 2002-2010 were greater than or equal to $M_{\text {max-snow }}$, and therefore $M_{\text {max-dryws }}$, which is the difference of these two values, was essentially zero (Table 5). However, for TDP, the water soluble fraction of dry deposition $\left(0.07 \mathrm{~kg} \mathrm{TDP} \mathrm{ha}^{-1}\right)$ was more than twice as much as that of wet deposition $\left(0.03 \mathrm{~kg} \mathrm{TDP} \mathrm{ha}^{-1}\right.$; Table 5). The mean particulate organic carbon (POC) loading was $2.8 \pm 0.76 \mathrm{~kg} \mathrm{Cha}^{-1}$ and represented an input of $>600 \mathrm{~kg}$ DOC to the watershed (Table 5). We calculated that $0.5 \pm 0.19 \mathrm{~kg} \mathrm{PN} \mathrm{ha}^{-1}$ and $0.05 \pm 0.01 \mathrm{~kg} \mathrm{PPha}^{-1}$ may be delivered to the GL4 catchment from dry deposition (Table 5). Particulate $\mathrm{Ca}^{2+}$ was not measured. 
Table 1. Precipitation (cm), volume weighted mean concentrations (all in $\mathrm{mg}^{-1}$, except TDP in $\mu \mathrm{g} \mathrm{l}^{-1}$ ), areal loadings (in $\mathrm{kg} \mathrm{ha}^{-1}$ ) of DOC and nutrients in wet deposition at the Soddie collector, and DOC and nutrient loadings (in kg) to the 225 ha Green Lake 4 (GL4) catchment*.

\begin{tabular}{|c|c|c|c|c|c|c|c|c|c|c|c|c|c|}
\hline \multirow[b]{2}{*}{ Year } & \multirow[b]{2}{*}{ Precip } & \multicolumn{3}{|c|}{ DOC } & \multicolumn{3}{|c|}{ TDN } & \multicolumn{3}{|c|}{ TDP } & \multicolumn{3}{|c|}{$\mathrm{Ca}^{2+}$} \\
\hline & & $\mathrm{C}_{\text {VWM }}$ & $\begin{array}{r}\text { Areal } \\
\text { ldg }\end{array}$ & $\begin{array}{r}\text { Ldg to } \\
\text { GL4 }\end{array}$ & $\mathrm{C}_{\mathrm{VWM}}$ & $\begin{array}{l}\text { Areal } \\
\text { ldg }\end{array}$ & $\begin{array}{r}\text { Ldg to } \\
\text { GL4 }\end{array}$ & $\mathrm{C}_{\mathrm{VWM}}$ & $\begin{array}{r}\text { Areal } \\
\text { ldg }\end{array}$ & $\begin{array}{r}\text { Ldg to } \\
\text { GL4 }\end{array}$ & $\mathrm{C}_{\mathrm{VWM}}$ & $\begin{array}{l}\text { Areal } \\
\text { ldg }\end{array}$ & $\begin{array}{r}\mathrm{Ldg} \text { to } \\
\text { GL4 }\end{array}$ \\
\hline 2002 & 48 & 1.19 & 5.7 & 1289 & 0.66 & 3.2 & 712 & 5.0 & 0.024 & 5 & 0.37 & 1.79 & 403 \\
\hline 2003 & 46 & 1.41 & 6.5 & 1452 & 0.51 & 2.3 & 525 & 2.2 & 0.010 & 2 & 0.25 & 1.14 & 257 \\
\hline 2004 & 81 & 0.77 & 6.2 & 1393 & 0.50 & 4.08 & 918 & 1.9 & 0.016 & 4 & 0.16 & 1.26 & 283 \\
\hline 2005 & 113 & 1.12 & 12.6 & 2844 & 0.42 & 4.78 & 1075 & 2.2 & 0.025 & 6 & 0.19 & 2.12 & 476 \\
\hline 2006 & 102 & 1.18 & 19.0 & 4276 & 0.57 & 5.9 & 1319 & 4.4 & 0.045 & 10 & 0.29 & 2.97 & 669 \\
\hline 2007 & 85 & 0.94 & 8.1 & 1813 & 0.52 & 4.45 & 1001 & 3.9 & 0.033 & 7 & 0.21 & 1.79 & 403 \\
\hline 2008 & 76 & 1.22 & 9.3 & 2098 & 0.43 & 3.25 & 731 & 2.8 & 0.022 & 5 & 0.33 & 2.50 & 562 \\
\hline 2009 & 93 & 1.25 & 11.7 & 2628 & 0.35 & 3.25 & 731 & 5.2 & 0.049 & 11 & 0.40 & 3.72 & 836 \\
\hline 2010 & 98 & 1.00 & 9.9 & 2220 & 0.29 & 2.83 & 637 & 4.4 & 0.043 & 10 & 0.68 & 6.7 & 1501 \\
\hline Mean & 83 & 1.12 & 9.9 & 2224 & 0.47 & 3.78 & 850 & 3.57 & 0.030 & 7 & 0.32 & 2.7 & 599 \\
\hline$\delta$ & 23 & 0.19 & 4.2 & 942 & 0.11 & 1.11 & 249 & 1.28 & 0.014 & 3 & 0.16 & 1.7 & 385 \\
\hline
\end{tabular}

$* \mathrm{C}_{\mathrm{VWM}}=$ volume weighted mean concentration; $\operatorname{ldg}=$ loading; $\delta=$ standard deviation.

Table 2. Volume weighted mean concentrations (all in $\mathrm{mg}^{-1}$, except TDP in $\mu \mathrm{g} \mathrm{l}^{-1}$ ), yields (in $\mathrm{kg}$ ) of DOC and nutrients from Green Lake 4 (GL4), and comparisons of wet deposition loading to lake yield*.

\begin{tabular}{|c|c|c|c|c|c|c|c|c|c|c|c|c|}
\hline Year & \multicolumn{3}{|c|}{ DOC } & \multicolumn{3}{|c|}{ TDN } & \multicolumn{3}{|c|}{ TDP } & \multicolumn{3}{|c|}{$\mathrm{Ca}^{2+}$} \\
\hline 2003 & 0.92 & 2200 & 0.66 & 0.31 & 1057 & 0.50 & 3.9 & - & - & 2.21 & 5284 & 0.05 \\
\hline 2004 & 0.96 & 1907 & 0.73 & 0.39 & 699 & 1.31 & 4.0 & - & - & 2.48 & 4953 & 0.06 \\
\hline 2007 & 0.87 & 1786 & 1.02 & 0.35 & 613 & 1.63 & 1.8 & 3.65 & 2.04 & 2.21 & 4552 & 0.09 \\
\hline 2008 & 1.15 & 2377 & 0.88 & 0.32 & 677 & 1.08 & 2.8 & 5.77 & 0.85 & 2.37 & 4893 & 0.11 \\
\hline 2009 & 0.92 & 1861 & 1.41 & 0.29 & 568 & 1.29 & 0.0 & - & - & 2.15 & 4354 & 0.19 \\
\hline Mean & 0.97 & 2007 & 1.10 & 0.31 & 693 & 1.40 & 2.79 & 5.77 & 1.38 & 2.25 & 4604 & 0.11 \\
\hline$\delta$ & 0.09 & 300 & 0.45 & 0.04 & 236 & 0.57 & 1.41 & 2.13 & 0.60 & 0.31 & 421 & 0.05 \\
\hline
\end{tabular}

${ }^{*} \mathrm{C}_{\mathrm{VWM}}=$ volume weighted mean concentration; $\delta=$ standard deviation; lake data for ice-free period (mid-May to mid-October); $-=$ data not available.

\subsection{Seasonal dynamics in wet deposition}

DOC concentrations in wet deposition showed a seasonal cycle of minima in the winter and maxima in the summer (Fig. 2). Wet deposition DOC loadings were significantly higher in the summer, particularly in July, than in other seasons (Fig. 3). Peaks in TDN concentrations were observed in the summer, and $\mathrm{Ca}^{2+}$ concentration peaks were observed in the spring (Fig. 2). TDP concentrations did not have a seasonal cycle, but most peaks occurred during the spring (Fig. 2). TDN and DON loadings were significantly higher in the summer than in the winter (Fig. 3). In contrast, $\mathrm{Ca}^{2+}$ loadings were significantly higher in the spring than in all other seasons (Fig. 3). The highest DOP loadings were also in the spring, and these were significantly higher than in the fall or winter (Fig. 3).
On 25 June 2002 and on 21 February 2006, two of the highest $\mathrm{Ca}^{2+}$ concentrations $\left(202 \mu \mathrm{eq}^{-1}\right.$ and $\left.534 \mu \mathrm{eq} \mathrm{l}^{-1}\right)$ corresponded to two of the highest DOC concentrations (10.9 $\mathrm{mg} \mathrm{Cl}^{-1}$ and $\left.7.1 \mathrm{mg} \mathrm{Cl}^{-1}\right)$. The 2006 peak occurred during a dust-in-snow deposition event (Rhoades et al., 2010), an event during which dust particles were deposited with precipitation as opposed to on the surface of the snow (dust-on-snow).

Linear regressions between log-transformed DOC and inorganic $\mathrm{N}\left(\right.$ as $\mathrm{NO}_{3}^{-}$) and $\mathrm{SO}_{4}^{2-}$ concentrations were significantly and positively correlated in the summer (Fig. 4). During spring and winter seasons, there were no relationships between these solutes, and in the fall the relationships were much less significant $\left(r^{2} \leq 0.35\right.$ for both). Summer concentrations of $\mathrm{NO}_{3}^{-}\left(\right.$mean $28.7 \pm 1.23 \mu \mathrm{eq}^{-1}$ ) and $\mathrm{SO}_{4}^{2-}$ (mean 
Table 3. Mean snow depth $(\mathrm{m})$, mean snow density $\left(\mathrm{g} \mathrm{m}^{-3}\right)$, and snow water equivalent $(\mathrm{m})$ at maximum accumulation (mid-May).

\begin{tabular}{cccc}
\hline Year & $\begin{array}{c}\text { Mean } \\
\text { snow } \\
\text { depth }\end{array}$ & $\begin{array}{c}\text { Mean } \\
\text { snow } \\
\text { density }\end{array}$ & SWE \\
\hline 2002 & 123 & 0.427 & 0.53 \\
2003 & 222 & 0.374 & 0.83 \\
2004 & 132 & 0.446 & 0.59 \\
2005 & 215 & 0.408 & 0.88 \\
2006 & 154 & 0.444 & 0.68 \\
2007 & 123 & 0.435 & 0.54 \\
2008 & 141 & 0.409 & 0.58 \\
2009 & 147 & 0.372 & 0.55 \\
2010 & 214 & 0.327 & 0.70 \\
\hline
\end{tabular}
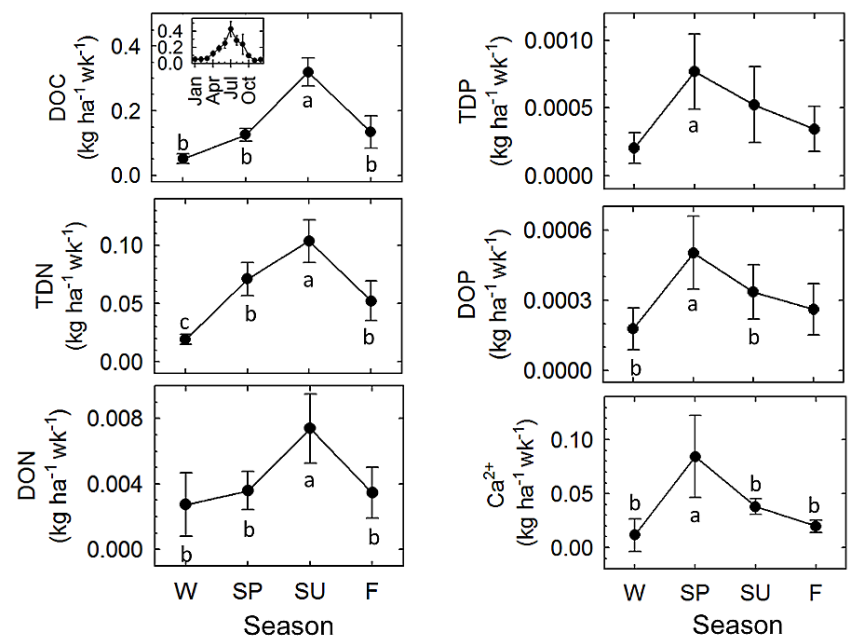

Fig. 3. Categorized means (by season; $\mathrm{W}=$ winter, $\mathrm{SP}=$ spring, $\mathrm{SU}=$ summer, $\mathrm{F}=$ fall) with $95 \%$ confidence intervals for DOC, TDN, DON, TDP, DOP, and $\mathrm{Ca}^{2+}$ measured at Soddie from 20022010. Values that are significantly different from one another are denoted with different lowercase letters. Inset shows highest DOC loading occurs during the month of July.

$19.1 \pm 1.07 \mu$ eq $\left.1^{-1}\right)$ were significantly higher $(p<0.0001$ for both) than concentrations for those solutes in other seasons.

\subsection{Dissolved organic matter quality of wet deposition}

DOC concentrations in wet deposition in 2010 peaked in the spring and summer (25 May, 20 July, and 27 July), similar to other years. SUVA values ranged from 0.1 to $2.61 \mathrm{mg}^{-1} \mathrm{~m}^{-1}$, and, in general, summer samples had the lowest SUVA values (Fig. 5). $S_{\mathrm{R}}$ values ranged from 0.8 to 2.9 with a mean value of 1.6 (Supplement Table S3). Mean $S_{275-295}$ and $S_{350-400}$ values were $0.018 \mathrm{~nm}^{-1}$ and $0.012 \mathrm{~nm}^{-1}$, respectively (Supplement Table S3). FI values ranged from 1.20 to 1.55 and showed great variability from

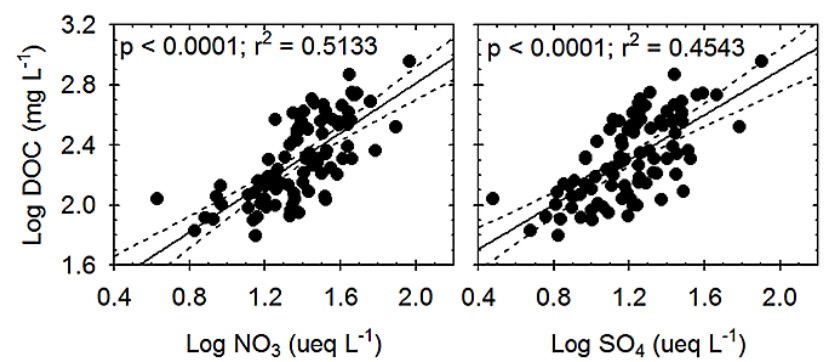

Fig. 4. Scatterplots of summer DOC concentration vs. $\mathrm{NO}_{3}^{-}$(left) and $\mathrm{SO}_{4}^{2-}$ (right) concentrations in wet deposition. Linear regressions with $95 \%$ confidence intervals and significant relationships are shown.

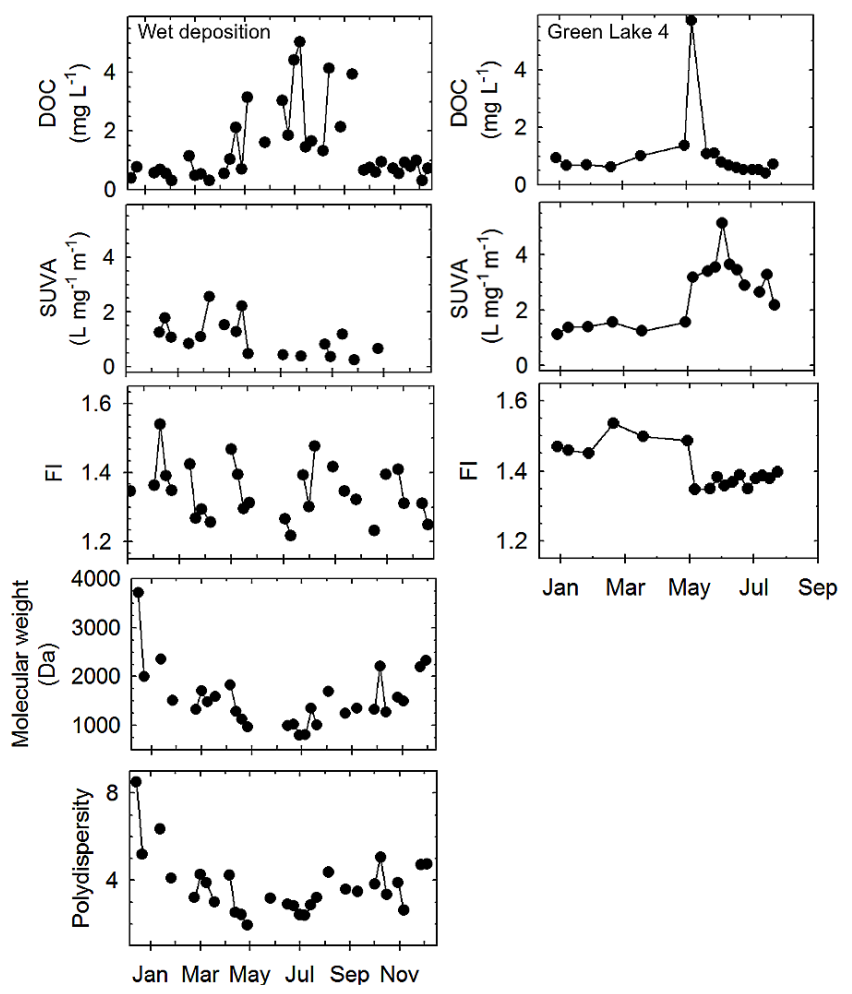

Fig. 5. Time series of DOC concentration, SUVA, FI, molecular weight, and polydispersity for 2010 wet deposition samples from the Soddie collector (left panels), and time series of DOC concentration, SUVA, and FI for 2010 water samples from Green Lake 4 (right panels).

week to week but no seasonal pattern (Fig. 5). In contrast to the fairly low SUVA values and highly variable FI in wet deposition, DOM in GL4 had fairly stable SUVA and FI values prior to snowmelt, (means of $1.41 \mathrm{mg} \mathrm{C}^{-1} \mathrm{~m}^{-1}$ and 1.48 , respectively) that shifted to higher SUVA values (mean of $3.61 \mathrm{mg} \mathrm{C}^{-1} \mathrm{~m}^{-1}$ ) and lower, but still stable, FI values (mean of 1.37) after snowmelt (Fig. 5).

SEC analyses showed that during the late spring and summer of 2010, the DOM in wet deposition was of fairly 
Table 4. DOC and nutrient concentrations (all in $\mathrm{mg}^{-1}$, except TDP in $\mu \mathrm{g} \mathrm{l}^{-1}$ ), areal loading (in $\mathrm{kg} \mathrm{ha}^{-1} \mathrm{yr}^{-1}$ ), and loading to the Green Lake 4 (GL4) catchment (in $\mathrm{kg} \mathrm{yr}^{-1}$ ) in snow at maximum accumulation* .

\begin{tabular}{|c|c|c|c|c|c|c|c|c|c|c|c|c|}
\hline \multirow[b]{2}{*}{ Year } & \multicolumn{3}{|c|}{ DOC } & \multicolumn{3}{|c|}{ TDN } & \multicolumn{3}{|c|}{ TDP } & \multicolumn{3}{|c|}{$\mathrm{Ca}^{2+}$} \\
\hline & $\mathrm{C}_{\max }$ & $\begin{array}{r}\text { Areal } \\
\text { ldg }\end{array}$ & $\begin{array}{r}\text { Ldg to } \\
\text { GL4 }\end{array}$ & $\mathrm{C}_{\max }$ & $\begin{array}{r}\text { Areal } \\
\text { ldg }\end{array}$ & $\begin{array}{r}\text { Ldg to } \\
\text { GL4 }\end{array}$ & $\mathrm{C}_{\max }$ & $\begin{array}{r}\text { Areal } \\
\text { ldg }\end{array}$ & $\begin{array}{l}\text { Ldg to } \\
\text { GL4 }\end{array}$ & $\mathrm{C}_{\max }$ & $\begin{array}{r}\text { Areal } \\
\text { ldg }\end{array}$ & $\begin{array}{r}\text { Ldg to } \\
\text { GL4 }\end{array}$ \\
\hline 2002 & 0.72 & 3.8 & 851 & 0.306 & 1.6 & 362 & 0.0066 & 0.03 & 8 & 0.306 & 1.6 & 361 \\
\hline 2003 & 0.34 & 2.8 & 635 & 0.207 & 1.7 & 387 & 0.0052 & 0.04 & 10 & 0.315 & 2.6 & 589 \\
\hline 2004 & 0.60 & 3.5 & 792 & 0.264 & 1.5 & 346 & 0.0025 & 0.01 & 3 & 0.130 & 0.8 & 170 \\
\hline 2005 & 0.36 & 3.2 & 712 & 0.259 & 2.3 & 512 & 0.0030 & 0.03 & 6 & 0.138 & 1.2 & 273 \\
\hline 2006 & 0.89 & 6.1 & 1373 & 0.205 & 1.4 & 315 & 0.0044 & 0.03 & 7 & 0.400 & 2.7 & 615 \\
\hline 2007 & 0.37 & 2.0 & 448 & 0.248 & 1.3 & 300 & 0.0034 & 0.02 & 4 & 0.150 & 0.8 & 181 \\
\hline 2008 & 0.42 & 2.4 & 545 & 0.209 & 1.2 & 271 & 0.0036 & 0.02 & 5 & 0.310 & 1.8 & 402 \\
\hline 2009 & 0.48 & 2.6 & 590 & 0.187 & 1.0 & 230 & 0.0054 & 0.03 & 7 & 0.427 & 2.3 & 525 \\
\hline 2010 & 0.65 & 5.1 & 1153 & 0.248 & 2.0 & 439 & 0.0066 & 0.05 & 12 & 0.467 & 3.7 & 828 \\
\hline Mean & 0.54 & 3.50 & 788 & 0.24 & 1.56 & 351 & 0.0045 & 0.030 & 7 & 0.29 & 1.95 & 438 \\
\hline$\delta$ & 0.19 & 1.33 & 299 & 0.04 & 0.38 & 87 & 0.0015 & 0.012 & 3 & 0.13 & 0.98 & 219 \\
\hline
\end{tabular}

* Ldg $=$ loading; $\delta=$ standard deviation.

Table 5. Maximum accumulation and mean annual values used to calculate the dry deposition areal $\left(\mathrm{kg} \mathrm{ha}^{-1} \mathrm{yr}^{-1}\right)$ and catchment (in parentheses; $\mathrm{kg} \mathrm{yr}^{-1}$ ) loadings of organic carbon $(\mathrm{OC})$, nitrogen $(\mathrm{N})$, phosphorus $(\mathrm{P})$, and calcium $(\mathrm{Ca})$, including water soluble (WS) and particulate (P) loadings, in the 225 ha Green Lake 4 catchment*.

\begin{tabular}{|c|c|c|c|c|c|}
\hline Parameter & Description & $\mathrm{OC}$ & $\mathrm{N}$ & $\mathrm{P}$ & $\mathrm{Ca}^{2+}$ \\
\hline \multicolumn{6}{|l|}{ Maximum accumulation } \\
\hline$M_{\text {max-snow }}$ & Snow & $3.5 \pm 1.33(788 \pm 299)$ & $1.6 \pm 0.4(351 \pm 87)$ & $0.03 \pm 0.01(8.0 \pm 2.0)$ & $2.0 \pm 1.0(438 \pm 219)$ \\
\hline$M_{\text {max-wet }}$ & Wet deposition & $3.6 \pm 0.9(810 \pm 213)$ & $1.9 \pm 0.5(419 \pm 120)$ & $0.01 \pm 0.005(2.0 \pm 1.2)$ & $2.0 \pm 1.6(461 \pm 357)$ \\
\hline$M_{\text {max-dryWS }}$ & Dry deposition water soluble & $0(0)$ & $0(0)$ & $0.02(5)$ & $0(0)$ \\
\hline$M_{\text {max-dryP }}$ & Dry deposition particulate & $1.0(225)$ & $0.2(52)$ & $0.02(4)$ & - \\
\hline \multicolumn{6}{|l|}{ Annual } \\
\hline$M_{\text {annual-wet }}: M_{\text {max-wet }}$ & $\begin{array}{l}\text { Ratio of annual : max accum } \\
\text { solutes in wet deposition }\end{array}$ & 2.8 & 2.0 & 2.7 & 1.3 \\
\hline$M_{\text {annual-wet }}$ & Wet deposition & $9.9 \pm 4.2(2228 \pm 942)$ & $3.8 \pm 1.1(855 \pm 249)$ & $0.03 \pm 0.01(7.0 \pm 3.1)$ & $2.7 \pm 1.7(608 \pm 385)$ \\
\hline$M_{\text {annual-dryWs }}$ & Dry deposition water soluble & $0(0)$ & $0(0)$ & $0.07(15)$ & $0(0)$ \\
\hline$M_{\text {annual-dryP }}$ & Dry deposition particulate & $2.8 \pm 0.76(619 \pm 170)$ & $0.5 \pm 0.19(106 \pm 42)$ & $0.05 \pm 0.01(12 \pm 2)$ & - \\
\hline \multicolumn{2}{|c|}{ Total annual wet + dry loading } & $12.7 \pm 5.0(2847 \pm 1142)$ & $4.3 \pm 1.3(961 \pm 291)$ & $0.15 \pm 0.02(34 \pm 5.1)$ & $2.7 \pm 1.7(608 \pm 385)$ \\
\hline $2002 M_{\text {annual-wet }}$ & Wet deposition & $5.7(1289)$ & $3.2(712)$ & $0.024(5)$ & $1.79(403)$ \\
\hline $2006 M_{\text {annual-wet }}$ & Wet deposition & $19.0(4276)$ & $5.9(1319)$ & $0.045(10)$ & $2.97(669)$ \\
\hline
\end{tabular}

* Dash indicates that particulate content was not measured for $\mathrm{Ca}^{2+}$.

moderate molecular weight (800-1200 Da; Fig. 5) and polydispersity (Supplement Table S3). Samples collected during the fall and winter of 2010 were of much higher molecular weight (> $1200 \mathrm{Da}$; Supplement Table S3). Average molecular weight and polydispersity were well correlated $(p<$ $0.01, r=0.938$ ), indicating that samples with higher average molecular weights, i.e., samples collected in the fall/winter, contained a more heterogeneous mixture.

EEMs from different dates of wet deposition also showed fairly diverse spectra (Fig. 6). Fitting to a PARAFAC model developed specifically for alpine watersheds identified $\mathrm{C} 2$, a fulvic-like component with an ex/em peak at $<240$ (290) / $406 \mathrm{~nm}$ that appears to be derived from both microbial and terrestrial sources (Mladenov et al., 2011; similar to C3 in Yamashita and Jaffe, 2008), as the most dominant component, representing $55 \pm 9 \%$ of the total fluorescence (Supplement Table S3). The concentration of C2 was significantly and positively related to DOC concentration (Fig. 7). C1, a component with an ex/em peak at $<240(340) / 492 \mathrm{~nm}$ that is related to terrestrial humic-like fluorescence in Yamashita and Jaffe (2008) and to the aerosol index in Mladenov et al. (2011), represented $28 \pm 9 \%$ of the total fluorescence, and its concentration was significantly and positively related to sulfate (Fig. 7). C1 was also negatively related to polydispersity (Fig. 7) and molecular weight. C3 (see C5 in Mladenov et al., 2011), a component with an ex/em peak at $340 / 414 \mathrm{~nm}$ that was found to be highly correlated to aromatic and phenolic $\mathrm{C}$ content (see C5 in Fellman et al. (2010)), represented $18 \pm 4 \%$ (Supplement Table S3). C3 is also in the range of the HULIS component identified in 

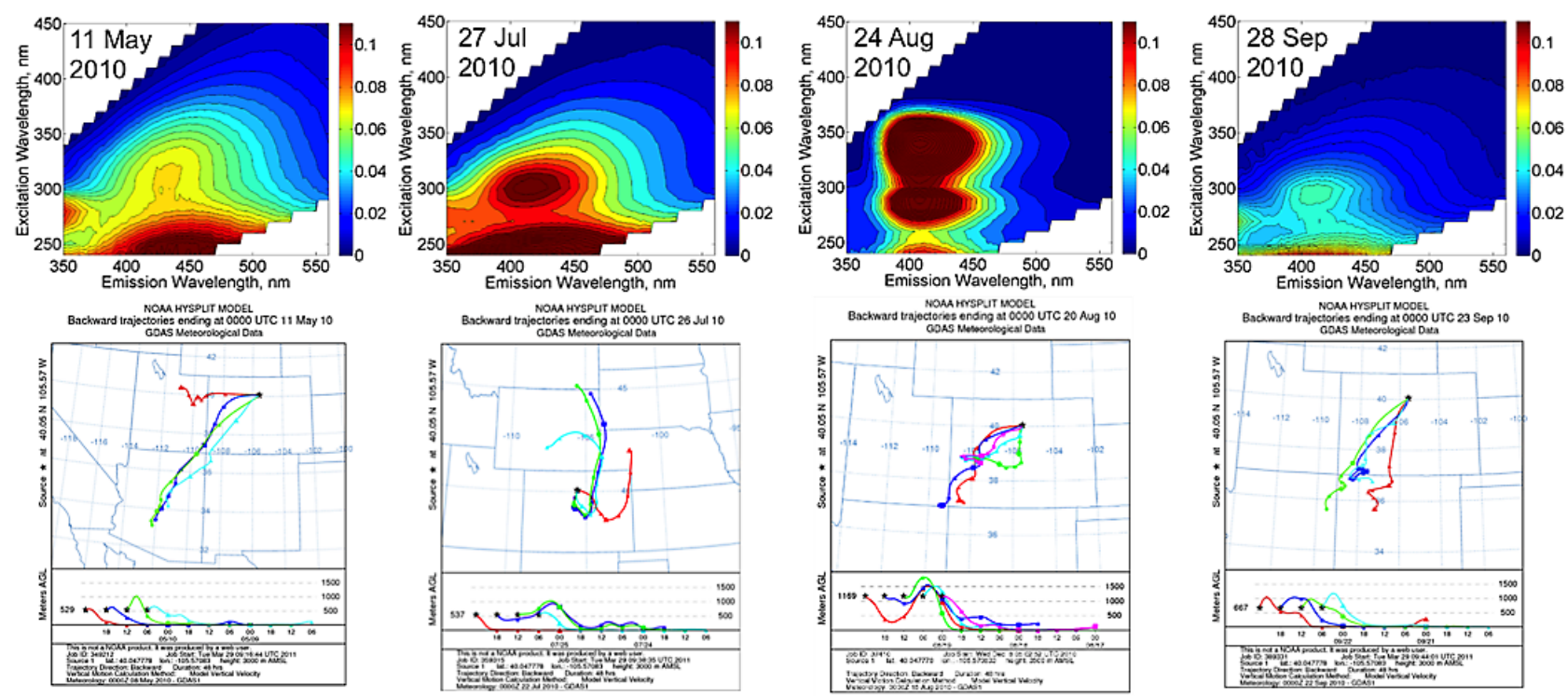

Fig. 6. Representative EEMs showing the diversity of fluorescence signatures from Soddie wet deposition. Samples collected on (a) 11 May 2010, (b) 27 July 2010, (c) 24 August 2010, and (d) 28 September 2010 are shown along with the corresponding backward trajectories ending on the date during which precipitation was measured at the NADP gage (date is specified in each backward trajectory figure). Although most backward trajectories show the air masses have similar origin near the Colorado Plateau, each EEM is quite different. Corresponding DOC concentrations were $2.1 \mathrm{mg}^{-1}, 5.1 \mathrm{mg}^{-1}, 1.3 \mathrm{mg} \mathrm{l}^{-1}$, and $4.0 \mathrm{mg} \mathrm{l}^{-1}$ for $\mathbf{a}, \mathbf{b}, \mathbf{c}$ and $\mathbf{d}$, respectively. Corresponding Ca ${ }^{2+}$ concentrations were $4.1 \mathrm{mg} \mathrm{l}^{-1}, 0.66 \mathrm{mg} \mathrm{l}^{-1}, 0.12 \mathrm{mg} \mathrm{l}^{-1}$ and $0.24 \mathrm{mg} \mathrm{l}^{-1}$ for $\mathbf{a}, \mathbf{b}, \mathbf{c}$ and $\mathbf{d}$, respectively. Corresponding TDN concentrations were $1.1 \mathrm{mgl}^{-1}, 0.91 \mathrm{mgl}^{-1}, 0.11 \mathrm{mg} \mathrm{l}^{-1}$ and $0.27 \mathrm{mg} \mathrm{l}^{-1}$ for $\mathbf{a , ~ b , ~} \mathbf{c}$ and $\mathbf{d}$, respectively. Corresponding TDP concentrations were $16 \mu \mathrm{g} \mathrm{l}^{-1}$, $0.8 \mu \mathrm{g} 1^{-1}, 0 \mu \mathrm{g} 1^{-1}$, and $4.7 \mu g 1^{-1}$ for $\mathbf{a}, \mathbf{b}, \mathbf{c}$ and $\mathbf{d}$, respectively.

Muller et al. (2008), which was found to increase under conditions of stagnant air and build up of pollutants in the atmosphere. Microbial, tyrosine-like and tryptophan-like components from the PARAFAC model (Mladenov et al., 2011) had maxima at $<350 \mathrm{~nm}$ emission and were excluded from this analysis.

\subsection{Pollen leaching and atmospheric inputs}

DOC leaching rates from 20-min, 24-h, and 1-week long experiments and for both types of pollen were very similar, ranging from 17 to $27 \mu \mathrm{g} \mathrm{Cg} \mathrm{g}^{-1}$ pollen (Table 6). For the week ending on 21 June 2011, the pollen count was 44714 grains $1^{-1}$ and the pollen contribution to wet deposition DOC was 0.034 to $0.043 \mathrm{mg} \mathrm{Cl}^{-1}$ (Table 6). Although these values represent $3.5 \%$ of the DOC concentration measured on 21 June $2011\left(1.13 \mathrm{mg} \mathrm{Cl}^{-1}\right)$, the values are within the analytical error and are, therefore, considered negligible. FI values were very low because the only peak was located at low emission wavelengths $(<400 \mathrm{~nm}$ emission), and essentially no fluorescence was present above $370 \mathrm{~nm}$ excitation (Supplement Fig. S2). SUVA values also could not be calculated because the absorbance at $254 \mathrm{~nm}$ was below the instrument detection limits.

\section{Discussion}

Here, we show new evidence that atmospheric wet and dry deposition of $\mathrm{C}$ and also $\mathrm{N}, \mathrm{P}$, and $\mathrm{Ca}^{2+}$ are important inputs of these elements to the carbon-poor and barren alpine soils at Niwot Ridge. In terms of DOC concentrations, the summer wet deposition values we measured, ranging from 4-10 $\mathrm{mg} \mathrm{Cl}^{-1}$, were higher than DOC concentrations in the snowpack (Table 3) and are high enough to be comparable to DOC concentrations found in temperate lakes (Sobek et al., 2007). The VWM DOC concentration for 2002-2010 wet deposition $\left(1.12 \pm 0.19 \mathrm{mg} \mathrm{Cl}^{-1}\right)$ is substantially higher than the mean DOC measured in coastal rain in New Zealand $\left(0.7 \mathrm{mg} \mathrm{Cl}^{-1}\right.$; Kieber et al., 2002) or the USA ( $\sim 0.6 \mathrm{mg} \mathrm{Cl}^{-1}$; Willey et al., 2000) and approaches the range of DOC in continental rain $\left(\sim 2 \mathrm{mg} \mathrm{Cl}^{-1}\right.$; Willey et al., 2000).

\subsection{Relevance of atmospheric wet and dry deposition in- puts for the catchment}

To assess the relevance of atmospheric inputs of $\mathrm{C}$ compared to other inputs and losses of $\mathrm{C}$ in the alpine, we estimated the total $\mathrm{C}$ budget for the GL4 catchment. For atmospheric deposition inputs to the GL4 catchment, we could not set up a collector in the GL4 catchment because it is a protected watershed supplying water to the City of Boulder, CO. Instead, 
a

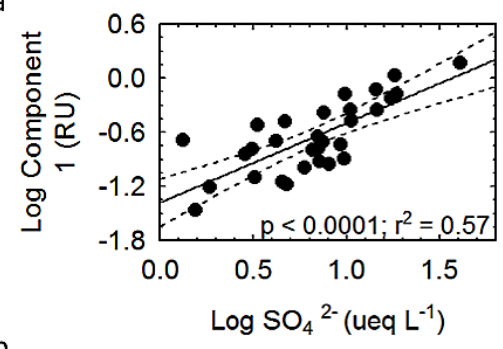

b
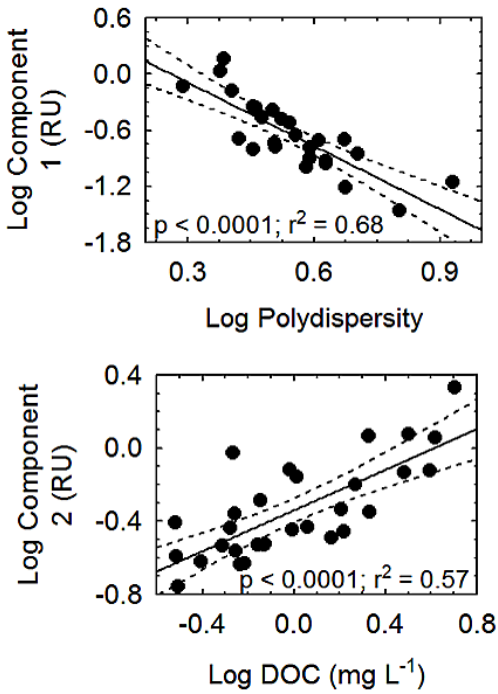

Fig. 7. Scatterplots of (a) fluorescent component 1 and sulfate concentration, (b) fluorescent component 1 and DOM polydispersity, and (c) fluorescent component 2 and DOC concentration in wet deposition in 2010. Linear regressions with $95 \%$ confidence intervals and significant relationships are shown.

we used values from the Soddie collector, which is about $4 \mathrm{~km}$ away from GL4 (Fig. 1). The Soddie wet deposition solute chemistry values were not significantly different from those at the NADP CO02 collector (Supplement Fig. S3), located $175 \mathrm{~m}$ higher and at almost the same elevation as GL4 (Fig. 1). For the $\mathrm{C}$ budget, the loadings associated with wet and dry deposition were $2200 \mathrm{~kg} \mathrm{C} \mathrm{yr}^{-1}\left(9.9 \mathrm{~kg} \mathrm{C} \mathrm{ha}^{-1} \mathrm{yr}^{-1}\right)$ and $600 \mathrm{kgC} \mathrm{yr}^{-1}\left(3 \mathrm{kgCha}^{-1} \mathrm{yr}^{-1}\right)$, respectively, and are significant when compared to the $\mathrm{C}$ yield (approximately $2000 \mathrm{~kg} \mathrm{C} \mathrm{yr}^{-1}$ ) from GL4. Given that only about $18 \%$ of the pollen influx in the mountains of western Colorado occurs from October to May (Fall, 1992), our dry deposition loading does not capture the majority of POC from pollen deposition. To account for this summer pollen input, we used the annual pollen deposition rate for a similar alpine tundra site in the Rocky Mountains (1092 grains cm $\mathrm{cm}^{-2} \mathrm{yr}^{-1}$; Fall, 1992) and the rate of $4.6 \times 10^{-8} \mathrm{~g} \mathrm{C}_{\text {grain }}{ }^{-1}$ pollen from our leaching experiments to determine an annual $\mathrm{POC}$ input from pollen of $0.5 \mathrm{~g} \mathrm{~m}^{-2} \mathrm{yr}^{-1}$ (> $1100 \mathrm{~kg} \mathrm{C} \mathrm{yr}^{-1}$ for GL4). This is comparable to the pollen deposition rate of $0.35 \mathrm{~g} \mathrm{C} \mathrm{m}^{-2} \mathrm{yr}^{-1} \mathrm{re}-$ ported for a remote site in Wisconsin (Doskey and Ugoagwu, 1989). Reducing the $0.5 \mathrm{~g} \mathrm{~m}^{-2} \mathrm{yr}^{-1}$ rate by $18 \%$ for the Oc- tober to May POC already included in the $\mathrm{C}$ budget calculation, summer pollen deposition is estimated to be an influx of roughly $900 \mathrm{~kg} \mathrm{C} \mathrm{yr}^{-1}\left(0.41 \mathrm{~g} \mathrm{~m}^{-2} \mathrm{yr}^{-1}\right)$ to the GL4 watershed. Therefore, the total wet $\left(2200 \mathrm{~kg} \mathrm{C} \mathrm{yr}^{-1}\right)$ and dry (900 kg C yr ${ }^{-1}$ from pollen and $600 \mathrm{~kg} \mathrm{C} \mathrm{yr}^{-1}$ from other aeolian deposition) inputs are approximately $3700 \mathrm{~kg} \mathrm{C} \mathrm{yr}^{-1}$ (16 $\mathrm{kg} \mathrm{Cha}^{-1} \mathrm{yr}^{-1}$ ) (Fig. 8). In years with high dust inputs, such as 2006 when the DOC input from wet deposition was $4300 \mathrm{~kg} \mathrm{C} \mathrm{yr}^{-1}\left(19 \mathrm{~kg} \mathrm{C} \mathrm{ha}^{-1} \mathrm{yr}^{-1}\right)$, the total atmospheric input could be $>5800 \mathrm{~kg} \mathrm{C} \mathrm{yr}^{-1}\left(24 \mathrm{~kg} \mathrm{Cha}^{-1} \mathrm{yr}^{-1}\right)$ (Table 5).

Whereas atmospheric deposition occurs year long and across the entire landscape, primary production in barren soils is more patchy, occurring mainly during the summer snow-free period (approximately 90d) (Freeman et al., 2009b) and over an area that is about half the talus area or roughly $20 \%$ of the watershed area (Erickson et al., 2005). Our calculations show that soil primary production inputs of approximately $10800 \mathrm{~kg} \mathrm{C} \mathrm{yr}^{-1}$ (calculated using the production rate of $240 \mathrm{~kg} \mathrm{Cha}^{-1} \mathrm{yr}^{-1}$ from Freeman et al. (2009b) over $20 \%$ of the watershed) are indeed higher than atmospheric inputs, as suggested by Freeman et al. (2009b). For barren soils, respiration C losses were calculated at approximately $12600 \mathrm{~kg} \mathrm{C} \mathrm{yr}^{-1}$, using an average 2002 summer season respiration rate of $56 \mathrm{~kg} \mathrm{Cha}^{-1} \mathrm{yr}^{-1}\left(0.013 \mathrm{~g} \mathrm{C} \mathrm{m}^{-2} \mathrm{~h}^{-1}\right.$; Freeman et al., 2009a), estimated to also occur for $90 \mathrm{~d}$ and over $20 \%$ of the watershed area. According to Caine (1995, and references therein), roughly $20 \%$ of the catchment also comprises lowlying vegetation. Primary production from aboveground vegetation was estimated at $67000 \pm 37000 \mathrm{~kg} \mathrm{C} \mathrm{yr}^{-1}$ (average of $150 \pm 82 \mathrm{~g} \mathrm{C} \mathrm{m}^{-2} \mathrm{yr}^{-1}$ for fellfield, dry meadow, moist meadow, shrub tundra, wet meadow, and snow bed vegetation; Bowman and Seasteadt, 2001 and references therein). However, aboveground respiration in the alpine zone of $\mathrm{Ni}$ wot Ridge is not as well studied. Blanken et al. (2009) found that a fellfield site at Niwot Ridge had transitioned from a $\mathrm{C}$ sink to a $\mathrm{C}$ source, with higher respiration than production. More recent findings by Knowles et al. (2012) support this observed increase in $\mathrm{C}$ export from this alpine environment. For the purposes of this $\mathrm{C}$ budget estimate, we used the winter respiration loss of $74000 \mathrm{~kg} \mathrm{C} \mathrm{yr}^{-1}\left(164 \mathrm{~g} \mathrm{C} \mathrm{m}^{-2} \mathrm{yr}^{-1}\right)$ from Blanken et al. (2009). However, given the changes described above, we recognize that this estimate of aboveground respiration is poorly constrained. Data for lake primary production and respiration were also not available. However, Ask et al. (2009) reported that the flux of C (production minus respiration) from clear, oligotrophic lakes in the arctic was net negative. Using their estimates of $60 \mathrm{~g} \mathrm{OC} \mathrm{m}^{-2}$ lake area $\mathrm{yr}^{-1}$, we calculated that lake respiration exceeded lake production by approximately $700 \mathrm{~kg} \mathrm{C}$ each year (Fig. 8).

Taking all inputs and losses of $\mathrm{C}$ and noting that there is also a pool of soil organic $C$ that may not be at steady state, we find that there is net export $\left(7800 \mathrm{~kg} \mathrm{C} \mathrm{yr}^{-1}\right)$ from the catchment. However, this export estimate is well below 


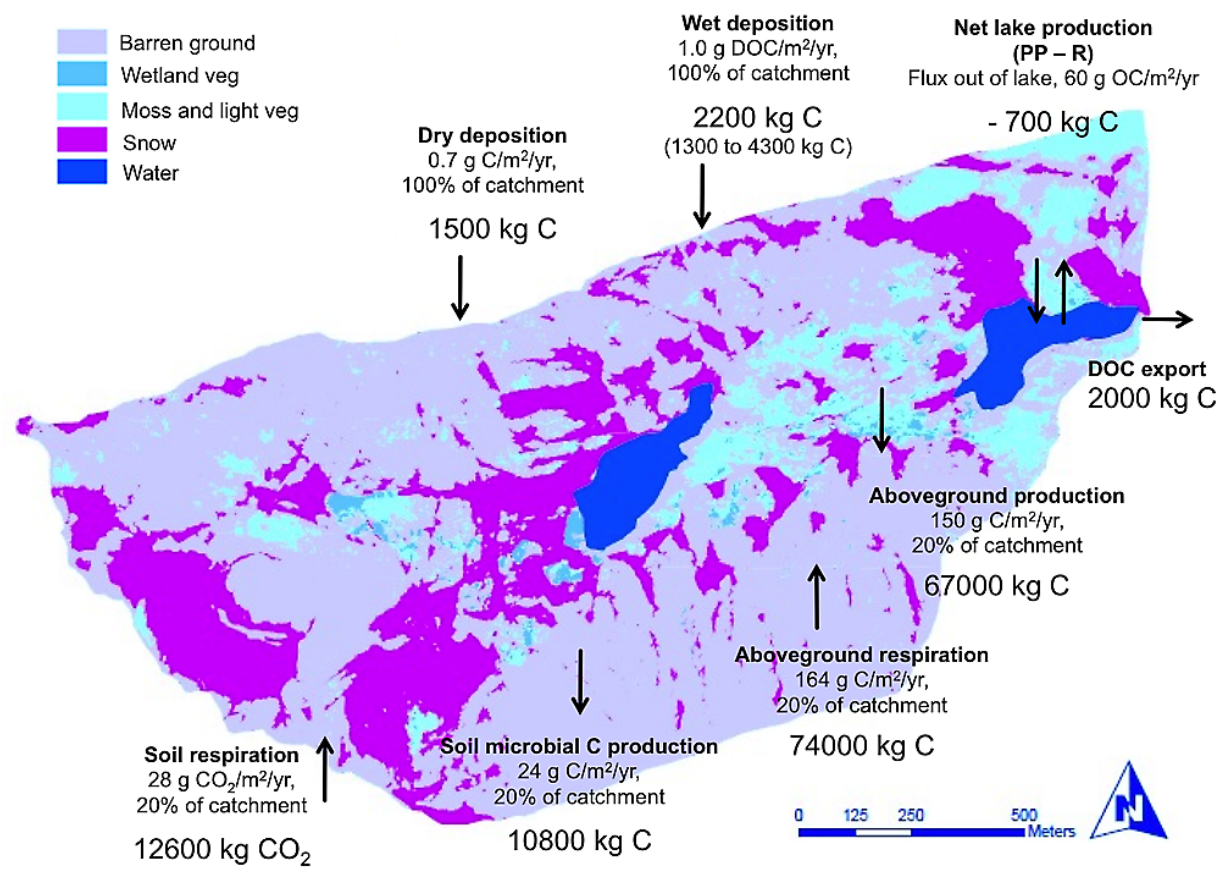

Fig. 8. Estimated annual C budget for the GL4 watershed overlaid on a land classification map from June 2008. Only major pools are included. Wet and dry deposition mean values and ranges are derived from long-term (2002-2010) weekly monitoring of wet deposition and snow at maximum accumulation. DOC export was taken as the mean annual yield from Green Lake 4. Other calculations are described in the Discussion. Art and GIS credit: Parrish, E.

the error associated with aboveground primary productivity ( $37000 \mathrm{~kg} \mathrm{Cyr}^{-1}$ ) and should be interpreted with caution. The value of this exercise was to place atmospheric $\mathrm{C}$ inputs in the context of an alpine $\mathrm{C}$ budget and compare them to other alpine $\mathrm{C}$ inputs and losses. Excluding the more highly productive tundra and meadow areas (Fig. 8) and considering the most barren and $\mathrm{C}$-limited parts of the watershed, our $\mathrm{C}$ budget illustrates that atmospheric $\mathrm{C}$ inputs can be $>30 \%$ of the $\mathrm{C}$ inputs from soil autotrophic primary production and as high as $50 \%$ when the 2006 (high dust year) wet deposition DOC input ( $\left.4300 \mathrm{~kg} \mathrm{Cyr}^{-1}\right)$ is used (Table 5). Given their potential bioavailability, these wet and dry inputs of organic $\mathrm{C}$ may be important for heterotrophs in this $\mathrm{C}$-limited but dynamic alpine environment.

Atmospheric $\mathrm{N}$ deposition has been extensively studied in the GL4 watershed (e.g., Williams et al., 1996, 2001; Darrouzet-Nardi et al., 2011). The combined wet and dry deposition $\mathrm{N}$ loading we measured $\left(4.3 \mathrm{~kg} \mathrm{Nha}^{-1}\right)$ is exactly in the range reported by Williams et al. (2001). Our results suggest that although there is net retention of $\mathrm{N}$ in the catchment, as shown by Williams et al. (2001), there is still substantial N export (at $690 \mathrm{~kg} \mathrm{~N} \mathrm{yr}^{-1}$ ) from the catchment. In contrast, the retention of $\mathrm{P}$ in the GL4 catchment is much greater. Compared to the combined atmospheric $\mathrm{P}$ inputs $\left(34 \mathrm{~kg} \mathrm{Pyr}^{-1}\right)$, the much lower export of P from GL4 (at $6 \mathrm{~kg} \mathrm{P} \mathrm{yr}^{-1}$ ) suggests that $\mathrm{P}$ is taken up in catchment soils and lakes. This high uptake of $\mathrm{P}(\sim 80 \%$ of the $\mathrm{P}$ input) further suggests that atmospheric $\mathrm{P}$ inputs are important for meeting the $\mathrm{P}$ demand of heterotrophic microbial populations in the barren talus soils of Niwot Ridge, which have been shown to be limited mainly by C, but also by P (King et al., 2008). We hypothesize that as a result of heterotrophic $\mathrm{C}$ processing, fueled by both atmospheric $\mathrm{C}$ and $\mathrm{P}$ and autochthonous $\mathrm{C}$ sources, the heterotrophic waste products (ammonium compounds) become available to autotrophs, such as nitrifying archaea and bacteria. There is mounting evidence that nitrate export from Rocky Mountain catchments has been decoupled from atmospheric $\mathrm{N}$ deposition and is due in part to increased nitrification in these catchments (Baron et al., 2009; Williams et al., 2001). Indeed, we observed substantial N export from the GL4 catchment, as described earlier. This linkage between a cascade of processes - atmospheric delivery of $\mathrm{C}$ and nutrients, heterotrophic and autotrophic microbial dynamics in barren soils, $\mathrm{N}$ export from alpine catchments, and changing headwater quality - is an important focus of our ongoing research.

In contrast to the high wet deposition to catchment yield ratios for DOC, TDN, and TDP, the input of dissolved $\mathrm{Ca}$ from wet deposition represented only $11 \%$ of the Ca yield (Table 2). The dry deposition input of Ca was not measured, but this input should be substantial because $\mathrm{Ca}$ is an important component of dust deposition in the Rocky Mountains 
(Lawrence et al., 2010). Indeed Clow et al. (1997) found that atmospheric wet and dry deposition inputs of Ca represented $>25 \%$ of the $\mathrm{Ca}$ export from a similar alpine/subalpine watershed in Loch Vale, Colorado, based on strontium tracer results. It is plausible that the atmospheric inputs are due to both long range aeolian transport and local redistribution. The high efflux of Ca we observed from the GL4 watershed may be largely due to the weathering of newly exposed rock surfaces in such areas as rock glaciers, where dissolved $\mathrm{Ca}$ concentrations can be as high as $80 \mathrm{mgl}^{-1}\left(4000 \mu \mathrm{eq} \mathrm{l}^{-1}\right)$ (Williams et al., 2006).

\subsection{Seasonality and sources of atmospheric deposition}

One important source of organic carbon in atmospheric deposition may be organic aerosol formation, which has been observed at Niwot Ridge (Boy et al., 2008). Boy et al. (2008) measured organic aerosol formation at Niwot Ridge and found that during nearly half of the sampling dates in June and July organic aerosols formed via reactions between atmospheric sulfuric acid and sesquiterpenes from sub-alpine vegetation. High summer concentrations of sulfur and nitrogen species in the atmosphere and in wet deposition attributed to urban and agricultural pollution have been measured at high-elevation sites in the Colorado Rocky Mountains (Malm et al., 2010; Beem et al., 2010), and we have measured significantly higher nitrate and sulfate in the summer than during other seasons at our site.

Another source of organic matter in atmospheric deposition may be organic pollutants themselves, which may be transported to higher elevations under upslope conditions. The prevailing winds at Niwot Ridge are almost exclusively westerlies during winter months, but there is a switch to occasional upslope (easterly) winds in the daytime during summer months (Blanken et al., 2009), which may transport urban and agricultural pollutants to higher elevations. From our observations it is difficult to determine whether we are measuring urban carbonaceous pollutants or organic aerosols formed from the vegetation-derived particle formation reactions described above. Willey et al. (2000) showed significant correlations between DOC concentrations and pollutant components, such as hydrogen ion, nitrate, and non-sea salt sulfate in summer non-tropical rain. Likewise, our correlations between DOC concentration and quality (polydispersity, terrestrial humic-like $\mathrm{C} 1$, and fulvic acid-like $\mathrm{C} 2$ ) and $\mathrm{SO}_{4}^{2-}$ in the summer (Fig. 6) may support both interpretations.

High summer DOC concentrations may also be related in part to the higher summer biological emissions and concentrations of biological particles in the atmosphere. Kieber et al. (2002) also observed higher DOC concentrations in summer rainfall that were attributed to terrestrial vegetation inputs. Peak pollen shedding at treeline in Colorado occurs in June and July, and there is anecdotal evidence of pollen in wet deposition from observations of "yellow par- ticles" in the collectors and retained on filters during this time (K. Chowanski and C. Seibold, personal communication, 2011). Our pollen counts in wet and dry deposition were highest in June and July (Goss et al., 2012). However, our pollen leaching experiments (Table 6) suggest that the contributions of WSOC from pollen are negligible.

In the spring, both inorganic and organic compounds are delivered in wet and dry deposition associated with dust. High $\mathrm{Ca}^{2+}$ and DOP content is characteristic of dust deposition to the Colorado Rocky Mountains from the Colorado Plateau and Mojave Desert (Lawrence et al., 2010), which is most pronounced during the spring. Three high $\mathrm{Ca}^{2+}$ precipitation events measured in 2010 (4, 11, and 18 May) had backward trajectories showing a Colorado Plateau air mass source (Supplement Fig. S5). Dust and biological particles are known ice nuclei (Prenni et al., 2009) with a direct influence on precipitation (Jaenicke, 2005). Therefore, it is not surprising that there are recurring springtime wet deposition peaks in $\mathrm{Ca}^{2+}$ and DOP (Fig. 2) that reflect springtime "dustin-snow" events. Without question, the $\mathrm{Ca}^{2+}$, DOP, and other aeolian rock- or soil-derived inputs associated with dust are constituents in wet and dry deposition whose influence on remote alpine sites should be further evaluated in light of their importance for ecosystem functioning (Morales-Baquero et al., 2006; Pulido-Villena et al., 2006).

In the spring, organic aerosols associated with dust may also be important sources of organic carbon in both wet and dry deposition. The three "dust-in-snow" events of 04 , 11 and 18 May 2010 had relatively high DOC loadings at 272, 137 and $415 \mathrm{~g} \mathrm{Cha}^{-1}$ week $^{-1}$, respectively. The EEMs for these dates resembled those from Saharan wet deposition (Mladenov et al., 2009), with a shoulder at ex/em $305 / 425 \mathrm{~nm}$ and a broad peak centered at approximately ex / em < 240/ 445 nm (see Fig. 6 for 11 May 2010 example). Another known dust-in-snow event, the storm of 21 February 2006 (Rhoades et al., 2010), was also associated with very high DOC concentrations and loadings $\left(>7 \mathrm{mg} \mathrm{Cl}^{-1}\right.$ and $410 \mathrm{~g} \mathrm{ha}^{-1}$ week $^{-1}$ ). Dry deposition at Niwot Ridge also contains substantial amounts of organic matter. Dust collector studies set up at Niwot Ridge (Litaor et al., 1987; Ley et al., 2004) found that dust comprised roughly $10 \%$ to $17 \%$ organic matter. Estimates of $0.42 \mathrm{~g} \mathrm{OC} \mathrm{m}^{-2} \mathrm{yr}^{-1}$ in dust from the Ley et al. (2004) study are higher but comparable to the POC loading in the snowpack at maximum accumulation we measured at Niwot Ridge $\left(0.28 \mathrm{~g} \mathrm{POC} \mathrm{m}^{-2} \mathrm{yr}^{-1}\right)$. The association of organic matter with dust at Niwot Ridge is consistent with recent hypotheses that dust transport is a vector for organic matter deposition globally (Mladenov et al., 2011).

\subsection{Chemical quality of $\mathrm{OC}$ in atmospheric deposition}

Given that there is a substantial amount of organic carbon in atmospheric deposition at Niwot Ridge, especially in the summer, its chemical quality and relevance for environmental processes are important questions. Our results 
Table 6. DOC and absorbance and fluorescence properties of pollen leachate and amount of wet deposition DOC due to pollen.

\begin{tabular}{|c|c|c|c|c|c|c|c|}
\hline Parameter & \multicolumn{2}{|c|}{ 20-min leaching } & \multicolumn{2}{|c|}{ 24-h leaching } & \multicolumn{2}{|c|}{ 1-week leaching } & Average \\
\hline \multicolumn{8}{|l|}{$\begin{array}{l}\text { Water extractable DOC from } \\
\text { pollen }^{\text {a }}\end{array}$} \\
\hline ( $\mu \mathrm{g} \mathrm{C}^{-1}$ pollen $)$ & $17 \pm 2.8$ & $25 \pm 4.7$ & 24 & 21 & 27 & 25 & 24 \\
\hline ( $\mu \mathrm{g} \mathrm{C}$ grain $^{-1}$ pollen) & 0.0525 & 0.0394 & - & - & - & - & - \\
\hline SUVA $\left(1 \mathrm{mg}^{-1} \mathrm{~m}^{-1}\right)$ & $u$ & $u$ & - & - & - & - & - \\
\hline $\begin{array}{l}\text { Amount of DOC on } 21 \text { June } 2011 \\
\text { due to pollen }\left(\mathrm{mg} \mathrm{Cl}^{-1}\right)^{b}\end{array}$ & 0.040 & 0.043 & 0.038 & 0.034 & 0.042 & 0.40 & 0.039 \\
\hline$\%$ DOC due to pollen ${ }^{c}$ & $3.5 \%$ & $3.8 \%$ & $3.3 \%$ & $3.0 \%$ & $3.7 \%$ & $3.5 \%$ & $3.5 \%$ \\
\hline
\end{tabular}

a SUVA values are not reported because the UV-vis absorbance at $254 \mathrm{~nm}$ was below instrument detection limits $(u)$. FI values are out of range (typically 1.2 to 1.7$)$ because there is essentially no fluorescence above $370 \mathrm{~nm}$ excitation in pollen-leached DOM (Supplement Fig. S2).

b The pollen count in wet deposition for the week ending on 21 June 2011 was 44714 pollen grains $1^{-1}$ week $^{-1}$.

c The DOC concentration on 21 June 2011 was $1.13 \mathrm{mg} \mathrm{Cl}^{-1}$.

from UV-vis absorbance spectroscopy suggest that the DOM in wet deposition was generally of low aromaticity (low SUVA values). Such low SUVA values further suggest that wet deposition DOM has been photobleached by UV radiation (Kieber et al., 2007). The high $S_{\mathrm{R}}$ and $S_{275-295}$ values and low MW we also measured, which often reflect photobleaching processes in aquatic ecoystems (Helms et al., 2008), were consistent with the observations of high spectral slopes of photobleached rainwater CDOM in Wilmington, NC, USA (Kieber et al., 2007). Greater blue-shifting (to shorter emission wavelengths) of dominant $\mathrm{A}$ and $\mathrm{C}$ peaks is often observed in EEM spectra of atmospheric WSOC compared to aquatic DOM and may be indicative of lower molecular weight compounds and general exposure of atmospheric aerosols to photo-oxidation processes that would act to decrease aromatic structures and unsaturated bond systems (Graber and Rudich, 2006 and references therein). The decrease in aromatic rings and other structural changes that reduce the extent of the $\pi$-electron system will increase the energy difference between ground state and the first excited state, which leads to blue-shifted fluorescence emission (Coble, 1996).

The decrease in molecular weight, polydispersity and aromaticity from photochemical transformations is known to improve substrate quality in aquatic ecosystems (Amon and Benner, 1996; Chin et al., 1998). However, little is known about how these measures of DOM quality relate to the bioavailability of DOM in atmospheric deposition. There is evidence, though, that some fraction of DOM in wet deposition is bioavailable. Willey et al. (2000) used low temperature dark incubations of rainfall samples collected at Wilmington, North Carolina, USA, to determine that $60 \%$ of the DOC was labile and $40 \%$ was resistant to bacterial degradation and was probably transported long distances. At Niwot Ridge or other C-limited alpine environments, such studies have not yet been performed, and the bioavailability of atmospheric organic matter or the influence of photochemical transformation on its bioavailability is not known. Nevertheless, we do know that alpine microorganisms may be able to degrade a wide range of $\mathrm{C}$ compounds. In experiments with $\mathrm{C}$-limited soils, bacteria responded to a more easily available $\mathrm{C}$ source (glucose) and fungi favored a more complex C source (cellulose) (Meidute et al., 2008). Alpine heterotrophic bacteria such as Polaromonas, found at Niwot Ridge and other barren alpine environments, can oxidize even recalcitrant carbon sources (Darcy et al., 2011 and references therein). At Niwot Ridge, chytrids have been found to dominate the fungal biodiversity (Freeman et al., 2009a) and are known to be partially supported by aeolian inputs, such as pollen. Therefore, the importance of atmospheric organic $\mathrm{C}$ inputs for these and other alpine organisms is a key question for future research.

\section{Conclusions}

Our results demonstrated that atmospheric deposition represents a substantial input of $\mathrm{C}, \mathrm{N}, \mathrm{P}$, and $\mathrm{Ca}^{2+}$ to the Green Lake 4 catchment. The atmospheric C input was $>30 \%$ of the $\mathrm{C}$ input from microbial autotrophic production in this $\mathrm{C}$-limited alpine catchment. Wet deposition DOC concentrations and loadings exhibited strong seasonality, and DOM in summer (and some spring) wet deposition events, which may be derived from air pollution, bioaerosol, and dust sources, was of lower MW and aromaticity than autumn or winter inputs. The influence of different aerosol sources and C quality on alpine biogeochemical processes is not known but is an important research question for studies at Niwot Ridge and other alpine and remote environments. Although our research provides an initial estimate of dry deposition loadings, more efforts to quantify and constrain this input are needed. Nevertheless, our dry deposition estimates suggest that dry deposition may be just as important as wet deposition for delivering $\mathrm{C}$ and $\mathrm{P}$ to alpine environments. 


\section{Supplementary material related to this article is available online at: http://www.biogeosciences.net/9/ 3337/2012/bg-9-3337-2012-supplement.pdf.}

Acknowledgements. We gratefully acknowledge the Kiowa Laboratory and C. Seibold, H. Hughes, S. Kim, H. Kim, E. Boor, N. Goss, J. Parman, and S. Lemons for laboratory assistance and K. Chowanski, J. Morse, and the Mountain Research Station for field assistance. We are also grateful to R. Jaffe for providing access to SEC determinations and for helpful review and comments on the manuscript. We thank E. Parrish for artistic contributions. Funding was provided by the National Science Foundation through grants for the Boulder Creek Critical Zone Observatory (EAR 0724960), NWT-LTER (DEB-1027341), Microbial Observatory (MCB-0455606), and Dust on Snow (EAR 1124576) and by the University of Colorado through Undergraduate Research Opportunities Program grants to S. Kim, H. Kim, and E. Boor. SEC work was funded through NSF as a collaboration with the FCE-LTER. This is SERC contribution \# 567.

Edited by: N. Ohte

\section{References}

Amon, R. M. W. and Benner, R.: Bacterial Utilization of Different Size Classes of Dissolved Organic Matter, Limnol. Oceanogr., 41, 41-51, 1996.

Ask, J., Karlsson, J., Persson, L. Ask, P., Bystro, P., and Jansson, M.: Whole-lake estimates of carbon flux through algae and bacteria in benthic and pelagic habitats of clear-water lakes, Ecology, 90, 1923-1932, 2009.

Ballantyne, A. P., Brahney, J., Fernandez, D., Lawrence, C. L., Saros, J., and Neff, J. C.: Biogeochemical response of alpine lakes to a recent increase in dust deposition in the Southwestern, US, Biogeosciences, 8, 2689-2706, doi:10.5194/bg-8-26892011, 2011.

Baron, J. S., Schmidt, T. M., and Hartman, M. D.: Climateinduced changes in high elevation stream nitrate dynamics, Global Change Biol., 15, 1777-1789, doi:10.1111/j.13652486.2009.01847.x, 2009.

Beem, K. B., Raja, S. Schwandner, F. M., Taylor, C., Lee, T., Sullivan, A. P., Carrico, C. M., McMeeking, G. R., Day, D., Levin, E., Hand, J., Kreidenweis, S. M., Schichtel, B., Malm, W. C., and Collett Jr., J. L.: Deposition of reactive nitrogen during the Rocky Mountain Airborne Nitrogen and Sulfur (RoMANS) study, Environ. Pollut., 158, 862-872, 2010.

Blanken P., Williams, M. W., Burns, S. P., Monson, R. K., Knowles, J., Chowanski, K., and Ackerman, T.: A comparison of water and carbon dioxide exchange at a windy alpine tundra and subalpine forest site near Niwot Ridge, Colorado, Biogeochemistry, 95, 61-67, doi:10.1007/s10533-009-9325-9, 2009.

Bowman, W. D. and Seastedt, T. R.: Structure and function of an alpine ecosystem: Niwot Ridge, Colorado, Oxford University Press, New York, 342 pp., 2001.

Boy, M., Karl, T., Turnipseed, A., Mauldin, R. L., Kosciuch, E., Greenberg, J., Rathbone, J., Smith, J., Held, A., Barsanti, K., Wehner, B., Bauer, S., Wiedensohler, A., Bonn, B., Kulmala, M., and Guenther, A.: New particle formation in the Front Range of the Colorado Rocky Mountains, Atmos. Chem. Phys., 8, 15771590, doi:10.5194/acp-8-1577-2008, 2008.

Brooks, P. D. and Williams, M. W.: Snowpack controls on nitrogen cycling, Hydrol. Process., 13, 2177-2190, 1999.

Brooks, P. D., Williams, M. W., and Schmidt, S. K.: Microbial activity under alpine snowpacks, Biogeochemistry 32, 93-113, 1996.

Brooks, P. D., Schmidt, S. K., and Williams, M. W.: Winter production of $\mathrm{CO}_{2}$ and $\mathrm{N}_{2} \mathrm{O}$ from alpine tundra: environmental controls and relationship to inter-system $\mathrm{C}$ and $\mathrm{N}$ fluxes, Oecologia 110, 403-413, 1997.

Caine, N.: Snowpack Influences on Geomorphic Processes in Green Lakes Valley, Colorado Front Range, Geogr. J., 161, 55-68, 1995.

Caine, N.: Streamflow patterns in the alpine environment of North Boulder Creek, ColoradoFront Range, Geomorphol., 1, 27-42, 1996.

Caine, N.: Recent hydrologic change in a Colorado alpine basin: an indicator of permafrost thaw?, Ann. Glaciol., 51, 130-134, 2011.

Chin, Y., Traina, S. J., Swank, C. R., and Backhus, D.: Abundance and Properties of Dissolved Organic Matter in Pore Waters of a Freshwater Wetland, Limnol. Oceanogr., 43, 1287-1296, 1998.

Clow, D. W., Mast, M. A., Bullen, T. D., and Turk, J. T.: Strontium 87 Strontium 86 as a Tracer of Mineral Weathering Reactions and Calcium Sources in an Alpine/Subalpine Watershed, Loch Vale, Colorado, Water Resour. Res., 1335-1351, 1997.

Coble, P. G.: Characterization of marine and terrestrial DOM in seawater using excitation-emission matrix spectroscopy, Mar. Chem., 51, 325-346, 1996.

Coble, P. G.: Marine Optical Biogeochemistry: The Chemistry of Ocean Color, Chem. Rev., 107, 402-418, 2007.

Darcy, J. L., Lynch, R. C., King, A. J., Robeson, M. S., and Schmidt, S. K.: Global distribution of Polaromonas phylotypes - evidence for a highly successful dispersal capacity, PloS ONE, 6, e23742, doi:10.1371/journal.pone.0023742, 2011.

Darrouzet-Nardi, A., Erbland, J., Bowman, W. D., Savarino, J., and Williams, M. W.: Landscape-level nitrogen import and export in an ecosystem with complex terrain, Colorado Front Range, Biogeochemistry, 109, 271-285, doi:10.1007/s10533-011-96258, 2011.

De Wit, H. A., Hindar, A., and Hole, L.: Winter climate affects long-term trends in stream water nitrate in acid-sensitive catchments in southern Norway, Hydrol. Earth Syst. Sci., 12, 393-403, doi:10.5194/hess-12-393-2008, 2008.

Draxler, R. R. and Rolph, G. D.: HYSPLIT (Hybrid Single-Particle Lagrangian Integrated Trajectory) Model access via NOAA ARL READY Website (http://www.arl.noaa.gov/ready/hysplit4.html), NOAA Air Resources Laboratory, Silver Spring, MD, 2003.

Doskey, P. V. and Ugoagwu, B. J.: Atmospheric deposition of macronutrients by pollen at a semi-remote site in northern Wisconsin, Atmos. Environ., 23, 12, 2761-2766, 1989.

Duarte, R. M. B. O., Pio, C. A., and Duarte, A. C. Spectroscopic study of the water-soluble organic matter isolated from atmospheric aerosols collected under different atmospheric conditions, Anal. Chim. Acta, 530, 7-14, 2005.

Duarte, R. M. B. O., Santos, E. B. H., Pio, C. A., and Duarte, A. C. Comparison of structural features of water-soluble organic matter from atmospheric aerosols with those of aquatic humic substances, Atmos. Environ., 41, 8100-8113, 2007. 
Economu, C. and Mihalopoulos, N.: Formaldehyde in the rainwater in the eastern Mediterranean: occurrence, deposition and contribution to organic carbon budget, Atmos. Environ., 36, 13371347, 2002.

Elser, J. J., Andersen, T. Baron, J. S., Bergström, A., Jansson, M., Kyle, M., Nydick, K. R., Steger, L., and Hessen, D. O.: Shifts in Lake N:P Stoichiometry and Nutrient Limitation Driven by Atmospheric Nitrogen Deposition, Science, 326, 835-837, doi:10.1126/science.1176199, 2009.

Erickson, T., Williams, M. W., and Winstral, A.: Persistence of topographic controls on the spatial distribution of snow depth in rugged mountain terrain, Colorado, USA, Water Resour. Res., 41, W04014, doi:10.1029/2003WR002973, 2005.

Fall, P. L.: Spatial patterns of atmospheric pollen dispersal in the Colorado Rocky Mountains, USA, Rev. Palaeobot. Palyno., 74, 293-313, 1992.

Fellman, J. B., Spencer, R. G. M., Hernes, P. J., Edwards, R. T., D'Amore, D. V., and Hood, E.: The Impact of Glacier Runoff on the Bioavailability and Biochemical Composition of Terrigeneous Dissolved Organic Matter in Near-Shore Marine Systems, Mar. Chem., 121, 112-122, 2010.

Freeman, K. R., Martin, A. P., Karki, D., Lynch, R. C., Mitter, M. S., Meyer, A. F., Longcore, J. E., Simmons, D. R., and Schmidt, S. K.: Evidence that chytrids dominate fungal communities in highelevation soils, P. Natl. Acad. Sci., 106, 18315-18320, 2009a.

Freeman, K. R., Pescador, M. Y., Reed, S. C., Costello, E. K., Robeson, M. S., and Schmidt, S. K.: Soil $\mathrm{CO}_{2}$ flux and photoautotrophic community composition in high-elevation, "barren" soils, Environ. Microbiol., 11, 674-686, 2009b.

Graber, E. R. and Rudich, Y.: Atmospheric HULIS: How humic-like are they? A comprehensive and critical review, Atmos. Chem. Phys., 6, 729-753, doi:10.5194/acp-6-729-2006, 2006.

Greenland, D.: The climate of Niwot Ridge, Front Range, Colorado, USA, Arctic Alpine Res., 24, 380-391, 1989.

Helms, J. R., Stubbins, A., Ritchie, J. D., and Minor, E. C., Kieber, D. J., and Mopper, K.: Absorption spectral slopes and slope ratios as indicators of molecular weight, source, and photobleaching of chromophoric dissolved organic matter, Limnol. Oceanogr., 53, 955-969, 2008.

Jaenicke, R.: Abundance of cellular material and proteins in the atmosphere. Science, 308, p. 73, 2005.

Jurado, E., Dachs, J., Duarte, C. M., and Simo, R.: Atmospheric deposition of organic and black carbon to the global oceans, Atmos. Environ., 42, 7931-7939, 2008.

Kieber, R. J., Peake, B., Willey, J. D., and Avery, G. B.: Dissolved organic carbon and organic acids in coastal New Zealand rainwater, Atmos. Environ., 36, 3557-3563, 2002.

Kieber, R. J., Whitehead, R. F., Reid, S. N., Willey, J. D., and Seaton, P. J.: Chromophoric dissolved organic matter (CDOM) in rainwater, southeastern North Carolina, USA, J. Atmos. Chem., 54, 21-41, doi:10.1007/s10874-005-9008-4, 2006.

Kieber, R. J., Willey, J. D., Whitehead, R. F., and Reid, S. N.: Photobleaching of chromophoric dissolved organic matter (CDOM) in rainwater, J. Atmos. Chem., 58, 219-235, 2007.

King, A. J., Meyer, A. F., and Schmidt, S. K.: High levels of microbial biomass and activity in unvegetated tropical and temperate alpine soils, Soil Biol. Biochem., 40, 2605-2610, 2008.
Kiss, G., Tombácz, E., Varga, B., Alsberg, T., and Persson, L.: Estimation of the average molecular weight of humic-like substances isolated from fine atmospheric aerosol, Atmos. Environ., 37, 3783-3794, 2003.

Knowles J. F., Blanken, P. D., Williams, M. W., and Chowanski, K. M.: Energy and surface moisture seasonally limit evaporation and sublimation from snow-free alpine tundra, Agr. Forest Meteorol., 157, 106-115, 2012.

Lawrence, C. R. and Neff, J. C.: The physical and chemical flux of eolian dust across the landscape: A synthesis of observations and an evaluation of spatial patterns, Chem. Geol., 267, 46-63, doi:10.1016/j.chemgeo.2009.02.005, 2009.

Lawrence, C. R., Neff, J. C., Painter, T., and Landry, C.: Contemporary composition of Aeolian dust deposited in the San Juan Mountains, Colorado, USA, J. Geophys. Res-Biogeo., 115, GO3007, doi:10.1029/2009JG001077, 2010.

Ley, R., Williams, M. W., and Schmidt, S.: Microbial population dynamics in an extreme environment: controlling factors in talus soils at $3750 \mathrm{~m}$ in the Colorado Rocky Mountains, Biogeochemistry, 68, 297-311, 2004.

Litaor, M. I.: The influence of eolian dust on the genesis of alpine soils in the Front Range, Colorado, Soil Sci. Soc. Am. J., 51, 142-147, 1987.

Maie, N., Watanabe, A., and Kimura, M.: Chemical characteristics and potential source of fulvic acids leached from the plow layer of paddy soil, Geoderma, 120, 309-323, 2004.

Malm, W. C., Schichtel, B. A., Barna, M. G., Gebhart, K. A., Collett, J. L., and Carrico, C. M.: Source apportionment of sulfur and nitrogen species at Rocky Mountain National Park using modeled conservative tracer releases and tracers of opportunity, in: Proceedings of the 29th Conf. on Agr. Forest Meteorol./19th Symposium on Boundary Layers and Turbulence/Ninth Symp, On the Urban Environment, Keystone, CO, 1-6 August, 2010.

McKnight, D. M., Boyer, E. W., Westerhoff, P. K., Doran, P. T., Kulbe, T., and Andersen, D. T.: Spectrofluorometric characterization of dissolved organic matter for indication of precursor organic material and aromaticity, Limnol. Oceanogr., 46, 38-48, 2001.

Meidute, S., Demoling, F., and Baath, E.: Antagonistic and synergistic effects of fungal and bacterial growth in soil after adding different carbon and nitrogen sources, Soil Biol. Biochem., 40, 2334-2343, 2008.

Mitchell, B. G., Kahru, M., Wieland, J., and Stramska, M.: Determination of spectral absorption coefficients of particles, dissolved material and phytoplankton for discrete water samples, in: Ocean optics protocols for satellite ocean color sensor validation. Revision 4. Vol. IV, edited by: Mueller, J. L., Fargion, G. S., and McClain, C. R., NASA/TM-2003-211621/R, Goddard Space Flight Center, Greenbelt, Md., 39-56, 2003.

Mladenov, N., López-Ramos, J., McKnight, D. M., and Reche, I.: Alpine lake optical properties as sentinels of dust deposition and global change, Limnol. Oceanogr., 54, 2386-2400, 2009.

Mladenov, N., Reche, I., Olmo-Reyes, F. J., Lyamani, H., and Alados-Arboledas, L.: Relationships between spectroscopic properties of high altitude organic aerosols and sun photometry from ground-based remote sensing, J. Geophys. Res.-Biogeo., 115, G00F11, doi:10.1029/2009JG000991, 2010. 
Mladenov, N., Sommaruga, R., Morales-Baquero, R., Camarero, L., Laurion, I., Diéguez, M. C., Camacho, A., Delgado, A., Torres, O., Chen, X., Felip, M., and Reche, I.: Dust inputs and bacteria influence dissolved organic matter in clear alpine lakes, Nature Comm., 2, 405, doi:10.1038/ncomms1411, 2011.

Morales-Baquero, R., Pulido-Villena, E., and Reche, I.: Atmospheric inputs of phosphorus and nitrogen to the southwest Mediterranean region: Biogeochemical responses of high mountain lakes, Limnol. Oceanogr., 51, 830-837, 2006.

Morris, D. P., Zagarese, H., Williamson, C. E., Balseiro, E. G., Hargreaves, B. R., Modenutti, B., Moeller, R., and Queimalinos, C.: The attenuation of solar UV radiation in lakes and the role of dissolved organic carbon, Limnol. Oceanogr., 40, 1381-1391, 1995.

Muller, C., Baker, A., Hutchinson, R., Fairchild, I. J., and Kidd, C.: Analysis of rainwater dissolved organic carbon compounds using fluorescence spectrophotometry, Atm. Environ., 42, 8036-8045, 2008.

Nakajima, H., Okada, K., Kuroki, Y., Nakama, Y., Handa, D., Arakaki, T., and Tanahara, A.: Photochemical formation of peroxides and fluorescence characteristics of the water-soluble fraction of bulk aerosols collected in Okinawa, Japan, Atm. Environ., 42, 3046-3058, 2008.

Neff, J. C., Ballantyne, A. P., Farmer, G. L., Mahowald, N. M., Conroy, J. L., Landry, C. C., Overpeck, J. T., Painter, T. H., Lawrence, C. R., and Reynolds, R. L.: Increasing eolian dust deposition in the western United States linked to human activity, Nat. Geosci., 1, 189-195, doi:10.1038/ngeo133, 2008.

Nemergut, D. R., Anderson, S. P., Cleveland, C. C., Martin, A. P., Miller, A. E., Seimon, A., and Schmidt, S. K.: Microbial community succession in unvegetated, recently-deglaciated soils, Microbial Ecology, 53, 110-122, 2007.

Prenni, A. J., Petters, M. D., Kreidenweis, S. M., Heald, C. L., Martin, S. T., Artaxo, P., Garland, R. M., Wollny, A. G., and Pöschl, U.: Relative roles of biogenic emissions and Saharan dust as ice nuclei in the Amazon basin, Nat. Geosci., 2, 402-405, doi:10.1038/NGEO517, 2009.

Psenner, R.: Living in a dusty world: airborne dust as a key factor for alpine lakes, Water Air Soil Pollut., 112, 217-227, 1999.

Pulido-Villena, E., Reche, I., and Morales-Baquero, R.: Significance of atmospheric inputs of calcium over the southwestern Mediterranean region: High mountain lakes as tools for detection, Global Biogeochem. Cy., 20, GB2012, doi:10.1029/2005GB002662, 2006.

Reche I., Ortega-Retuerta, E., Romera, O., Pulido-Villena, E., Morales-Baquero, R., and Casamayor, E. O.: Effect of Saharan dust inputs on bacterial activity and community composition in Mediterranean lakes and reservoirs, Limnol. Oceanogr., 54, 869879, 2009.

Rhoades, C., Elder, K., and Greene, E.: The Influence of an Extensive Dust Event on Snow Chemistry in the Southern Rocky Mountains, Arct. Antarct. Alp. Res., 42, 98-105, 2010.

Rogora, M.: Synchronous trends in $\mathrm{N}^{-\mathrm{NO}_{3}}$ export from N-saturated river catchments in relation to climate, Biogeochemistry, 86, 251-268, 2007.

Schmidt, S. K., Reed, S. C., Nemergut, D. R., Grandy, A. S., Cleveland, C. C., Costello, E. K., Weintraub, M. N., Hill, A. W., Meyer, A. F., Martin, A. P., and Neff, J. C.: The earliest stages of ecosystem succession in high-elevation (5000 meters above sea level), recently de-glaciated soils, P. Roy. Soc. B, 275, 2793-
2802, doi:10.1098/rspb.2008.0808, 2008.

Schmidt S. K., Nemergut, D. R., Miller, A. E., Freeman, K. R., King, A. J., and Seimon, A.: Microbial activity and diversity during extreme freeze-thaw cycles in periglacial soils, $5400 \mathrm{~m}$ elevation, Cordillera Vilcanota, Perú, Extremophiles, 13, 807-816, doi:10.1007/s00792-009-0268-9, 2009.

Sickman, J. O., Leydecker, A. L., Chang, C. C. Y., and Kendall, C.: Mechanisms underlying export of $\mathrm{N}$ from high-elevation catchments during seasonal transitions, Biogeochemistry, 64, 1-24, doi:10.1023/A:1024928317057, 2003.

Scully, N. M., Maie, N., Dailey, S. K., Boyer, J. N., Jones, R. D., and Jaffe, R.: Early diagenesis of plant-derived dissolved organic matter along a wetland, mangrove, estuary ecotone, Limnol. Oceanogr., 49, 1667-1678, 2004.

Sobek, S., Tranvik, L. J., Prairie, Y. T., Kortelainen, P., and Cole, J. J.: Patterns and regulation of dissolved organic carbon: An analysis of 7500 widely distributed lakes, Limnol. Oceanogr., 52, 1208-1219, 2007.

Stedmon, C. A. and Bro, R.: Characterizing dissolved organic matter fluorescence with parallel factor analysis: a tutorial, Limnol. Oceanogr.-Meth., 6, 572-579, 2008.

Stedmon, C. A., Markager, S., and Bro, R.: Tracing dissolved organic matter in aquatic environments using a new approach to fluorescence spectroscopy, Mar. Chem., 82, 239-254, 2003.

Weishaar, J. L., Aiken, G. R., Bergamaschi, B. A., Fram, M. S., Fujii, R., and Mopper K.: Evaluation of Specific Ultraviolet Absorbance as an Indicator of the Chemical Composition and Reactivity of Dissolved Organic Carbon, Environ. Sci. Technol., 37, 4702-4708, 2003.

Willey, J. D., Kieber, R. J., Eyman, M. S., and Avery Jr., G. B.: Rainwater dissolved organic carbon: concentrations and global flux, Global Biogeochem. Cy., 14, 139-148, 2000.

Williams, M. W. and Tonnessen, K. A.: Critical loads for inorganic nitrogen deposition in the Colorado Front Range, USA, Ecol. Appl., 10, 1648-1665, 2000.

Williams, M. W., Tonnessen, K., Melack, J., and Yang D.: Sources and spatial variation of the solute content of snow in the Tien Shan, PR China, Ann. Glaciol., 16, 25-32, 1992.

Williams, M. W., Baron, J., Caine, N., Sommerfeld, R., and Sanford, R.: Nitrogen saturation in the Colorado Front Range, Environ. Sci. Technol., 30, 640-646, 1996.

Williams, M. W., Davinroy, T., and Brooks, P. D.: Organic and inorganic nitrogen pools in talus soils and water, Green Lakes Valley, Colorado Front Range, Hydrol. Process., 11, 1747-1760, 1997.

Williams, M. W., Cline, D., Hartmann, M., and Bardsley, T.: Data for snowmelt model development, calibration, and verification at an alpine site, Colorado Front Range, Water Resour. Res., 35, 3205-3209, 1999.

Williams, M. W., Hood, E., and Caine, N.: The role of organic nitrogen in the nitrogen cycle of a high-elevation catchment, Colorado Front Range, USA, Water Resour. Res., 37, 2569-2582, 2001.

Williams, M. W., Knauf, M., Caine, N., Liu, F., and Verplanck, P.: Geochemistry and Source Waters of Rock Glacier Outflow, Colorado Front Range, Permafrost Periglac., 17, 13-33, 2006.

Williams, M. W., Knauf, M., Cory, R., Caine, N., and Liu, F. J.: Nitrate content and potential microbial signature of rock glacier outflow, Colorado Front Range, Earth Surf. Proc. Land., 32, 1032-1047, doi:10.1002/esp.1455, 2007. 
Williams M. W., Seibold, C., and Chowanski, K.: Storage and Release of Solutes from a Subalpine Seasonal Snowpack: Soil and Stream Water Response, Niwot Ridge, Colorado, Biogeochemistry, 95, 77-94, doi:10.1007/s10533-009-9288-x, 2009.

Williams, M. W., Barnes, R. T., Parman, J. N., Freppaz, M., and Hood, E.: Stream Water Chemistry along an Elevational Gradient from the Continental Divide to the Foothills of the Rocky Mountains, Vadose Zone J., 10, 900-914, doi:10.2136/vzj2010.0131, 2011.
Wolfe, A. P., Baron, J. S., and Cornett, R. J.: Anthropogenic nitrogen deposition induces rapid ecological changes in alpine lakes of the Colorado Front Range (USA), J. Paleolimnol., 25, 1-7, doi:10.1023/A:1008129509322, 2001.

Yamashita, Y. and Jaffe, R.: Characterizing the Interactions Between Trace Metals and Dissolved Organic Matter Using Excitation-Emission Matrix and Parallel Factor Analysis, Environ. Sci. Technol., 42, 7374-7379, 2008. 